OPEN ACCESS

Edited by: Dongju Zhang,

Lanzhou University, China

Reviewed by:

Chunxue Wang,

Jilin University, China

Geoffrey Smith,

Max Planck Institute for Evolutionary

Anthropology, Germany

*Correspondence:

Shuangquan Zhang

zhangshuangquan@ivpp.ac.cn

Specialty section:

This article was submitted to Quaternary Science, Geomorphology

and Paleoenvironment,

a section of the journal

Frontiers in Earth Science

Received: 22 November 2021 Accepted: 28 January 2022

Published: 16 February 2022

Citation:

Zhang Y, Doyon L, Peng F, Wang $H$, Guo J, Gao X and Zhang S (2022) An Upper Paleolithic Perforated Red Deer Canine With Geometric Engravings From QG10, Ningxia, Northwest China.

Front. Earth Sci. 10:814761. doi: 10.3389/feart.2022.814761

\section{An Upper Paleolithic Perforated Red Deer Canine With Geometric Engravings From QG10, Ningxia, Northwest China}

\author{
Yue Zhang ${ }^{1,2}$, Luc Doyon ${ }^{3,4}$, Fei Peng ${ }^{5}$, Huimin Wang ${ }^{6}$, Jialong Guo ${ }^{6}$, Xing Gao ${ }^{1,2,7}$ and \\ Shuangquan Zhang ${ }^{1,2,7 *}$ \\ ${ }^{1}$ Key Laboratory of Vertebrate Evolution and Human Origins, Institute of Vertebrate Paleontology and Paleoanthropology, Chinese \\ Academy of Sciences, Beijing, China, ${ }^{2}$ CAS Center for Excellence in Life and Paleoenvironment, Beijing, China, ${ }^{3}$ CNRS UMR5199 \\ PACEA, Université de Bordeaux, Bordeaux, France, ${ }^{4}$ Institute of Cultural Heritage, Shandong University, Qingdao, China, \\ ${ }^{5}$ Department of Archaeology and Museology, Minzu University of China, Beijing, China, ${ }^{6}$ Ningxia Institute of Cultural Relics and \\ Archaeology, Yinchuan, China, ${ }^{7}$ School of Earth and Planetary, University of Chinese Academy of Sciences, Beijing, China
}

Personal ornaments are key archaeological remains to investigate prehistoric symbolic systems, and, whenever hard animal remains were used for their manufacture, explore topics on the status attributed to faunal resources by past human groups. Since the onset of the Upper Paleolithic, animal tooth pendants have been widely used in Eurasia as personal adornments or grave goods. However, only two Late Paleolithic Chinese sites have yielded such adornment types until today, i.e., Zhoukoudian Upper Cave, near Beijing, and Xiaogushan, in the Liaoning Province. Here, we present results from the multidisciplinary analysis of a perforated animal tooth from QG10, a multi-stratified archaeological site located on the Ordos Plateau between the arid and sub-arid belts of Northwest China. Although only partially preserved, zooarchaeological analysis indicates the tooth is a right upper canine of a female red deer (Cervus elaphus). Scraping marks on the labial aspect suggest the tooth was extracted from the animal maxillary shortly after its death. Technological analysis of the perforation confirms it was made by rotation with the help of a lithic point hafted onto a drill. The root and occlusal aspect of the tooth were further modified with five sets of notches and incisions, including four incisions making a hashtag pattern on the occlusal aspect. Technological and morphometric analyses indicate these sets were made by two, perhaps three, individual, i.e., one left-handed and one, perhaps two right-handed, with different tools and techniques. Use wear analysis suggests that the adornment was affixed to the body with the tooth crown facing upward. Finally, chemical characterization of red and black residues still adhering to the root indicates that hematite and charcoal may have been used in the production of an adhesive that would have helped stabilize the personal ornament on the body. Collectively, our results and interpretations shed a new light on the complexity of Late Glacial symbolic system carried by populations living in Northern China. We argue this perforated red deer tooth was introduced in the site following a number of social exchanges over long distance and a long period of time rather than produced in situ. 


\section{INTRODUCTION}

Personal ornaments are key archaeological remains to investigate prehistoric symbolic behaviors. In traditional societies, these objects appear to have played a crucial role in signaling individual and group identity in social interactions, and sometimes, acting as valuable goods that were exchanged to consolidate the relationships between members belonging to the same or different groups (Malinowski, 1922; Kuper, 1973; Brain, 1979; Cordwell and Schwarz, 1979; Hodder, 1982; Carey, 1986; Kassam, 1988; Morris and Preston-Whyte, 1994; Sanders, 2002; Joyce, 2005; McAdam, 2008; Casella, 2012; Hart et al., 2016; McAdam and Davidson, 2018; Balme and O'Connor, 2019). Research conducted over the last 2 decades has vastly expanded our understanding on the origin and development of personal ornamentation practices during the Prehistory. We now know that this aspect of material culture was well-establish in the cultural system of populations living in the Levant and Africa around $120 \mathrm{ka}$ (Bouzouggar et al., 2007; Steele et al., 2019; Vanhaeren et al., 2019; Bar-Yosef Mayer et al., 2020; d'Errico et al., 2020). A recent discovery from Bizmoune Cave, southwest Morocco, further suggests that the origin of this behavior may be pushed back to $142 \mathrm{ka}$ on the African continent (Sehasseh et al., 2021). Between 120 and $65 \mathrm{ka}$, personal ornaments are essentially made of ostrich eggshells and marine shells. Between 65 and $45 \mathrm{ka}$, there is a hiatus in the production of personal ornaments in Africa and the Levant. When these items re-emerge in the archaeological record $c .45 \mathrm{ka}$, they are found throughout the Old World (Vanhaeren and d'Errico, 2006; Pitulko et al., 2012; Stiner et al., 2013; Wei et al., 2016; Wei et al., 2017; Pitarch Martí et al., 2017; Shidrang, 2018; Bosch et al., 2019; Langley et al., 2019, 2020; Bar-Yosef Mayer et al., 2020; Shunkov et al., 2020; Tejero et al., 2020). Furthermore, the prehistoric human groups making these objects appear to have broaden the variety of raw materials and supports considered fit for their transformation into items of symbolic material culture. For the first time, perforated animal teeth are introduced as displayed items in the symbolic systems of early Upper Paleolithic populations (e.g., Vanhaeren and d'Errico, 2006; d'Errico and Vanhaeren, 2015; Shunkov et al., 2020).

A number of studies aimed to understand how personal ornaments could inform us on prehistoric social and population dynamics. Large-scale investigation of some European Upper Paleolithic traditions (Vanhaeren and d'Errico, 2006; d'Errico and Vanhaeren, 2015), of the ornamental practices during the Mesolithic to Neolithic transition (Rigaud et al., 2015; Rigaud et al., 2018) or carried by Aboriginal Australians (McAdam, 2008; Balme and O'Connor, 2019) have shed light on variations in the type of ornaments found various sites. Through multi-variate analyses, it was possible to circumscribe geographic boundaries of these traditions and explore the degree of interactions bearers of these distinct traditions may have engaged in.

In Northern China, the manufacture and use of personal ornaments is a phenomenon restricted to the Late Paleolithic; a little over a dozen sites have yielded such objects in this vast region. Furthermore, despite being mentioned in reports, detailed technological analysis-and, whenever possible, the chemical characterization of adhering colorants-is available only for a handful of sites. Early evidence comes from Shuidonggou Localities 2, 7 and 8 (Pei et al., 2012; Wei et al., 2016; Wei et al., 2017; Pitarch Martí et al., 2017; Feng Li et al., 2019) in the Ordos Plateau and, Zhoukoudian Upper Cave near Beijing (Pei, 1939; d'Errico et al., 2021) as well as Xiaogushan, Liaoning Province (Huang et al., 1986). The Shuidonggou sites mainly yielded ostrich eggshell beads (OESBs) and some rare ornaments made from freshwater shells, while diversified ornamentation assemblages dominated by mammal teeth were found at sites located to the East. A recent seriation of Northern Chinese personal ornament highlighted a clear divide in the distribution of the bead types between sites located east and west of the $112^{\circ} \mathrm{E}$ longitude (d'Errico et al., 2021). The western tradition, to which the Shuidonggou site complex belongs, mainly focused on the manufacture of OESBs and this symbolic system seems to be maintained for much of the Late Paleolithic, i.e., from 45 to $10 \mathrm{ka}$. On the contrary, and in spite of its initial diversity, the eastern tradition disappeared from the archaeological record $c$. $25 \mathrm{ka}$. From that date until the Chinese Neolithic, mammal teeth appear to be disregarded by prehistoric human groups as a befitting raw material for the manufacture of ornaments. This strong regional and temporal pattern raises the question as to what happened to this cultural tradition.

Here, we report the discovery of a perforated red deer canine. This object is peculiar for three reasons. First, it comes from a site located in the aforementioned "western tradition" and from a context dated to $c .13 \mathrm{ka}$. Second, it was found in a layer that also yielded OESBs, the typical ornament type for the "western tradition." Third, the perforated tooth was further modified with five sets of decorative patterns. Our technological analysis suggests the tooth was extracted from a hunted hind aged between 6 and 11 years-old. It allows us to describe how the tooth was transformed into a personal ornament and worn in the past. A careful examination of the decoration made on the tooth suggests the markings were made by at least two, perhaps three individuals, which suggests the object was passed down to as many owners prior to being discarded at the site. This specimen sheds a new light on the complexity of Late Glacial symbolic system carried by populations living in Northern China.

\section{MATERIAL AND METHODS}

\subsection{Archaeological Context}

The remain documented here was found during the excavation at the Locality 10 of the Pigeon Mountain site complex. In the literature, the site is either referred to as "Pigeon Mountain Loc. 10" (Peng et al., 2017; Guan et al., 2020; Han 2021) or it is Chinese pinyin equivalent, i.e., “Gezishan Loc. 10” (Zhang et al., 2019). Here, we use the short name QG10, which stands for Qingtongxia Gezishan Loc. 10. Located on the foothills of the Helan Mountains, c. $20 \mathrm{~km}$ north-west of the Qingtongxia City, Ningxia Hui Autonomous Region, China (Figure 1; $\mathrm{N} 38^{\circ} 03^{\prime} 33.1^{\prime \prime}, \mathrm{E} 105^{\circ} 50^{\prime} 30.3^{\prime \prime}$, altitude ca. $1,200 \mathrm{~m}$ ), the site was systematically excavated from 2014 to 2017 . The excavated area 


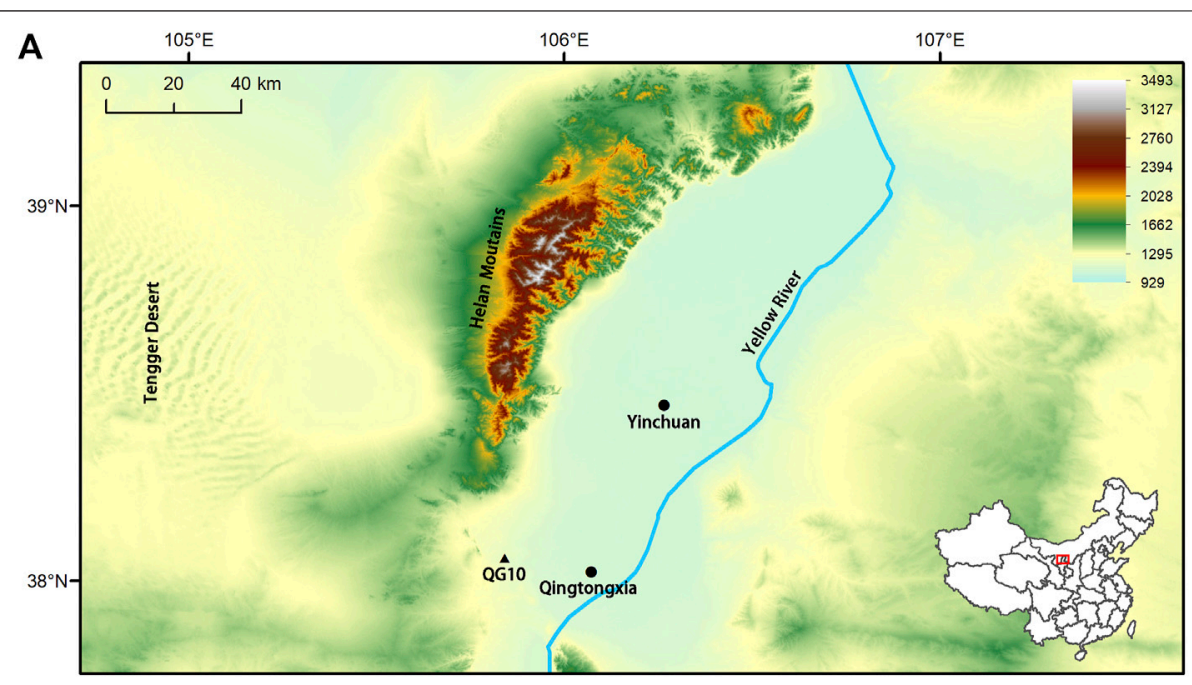

B

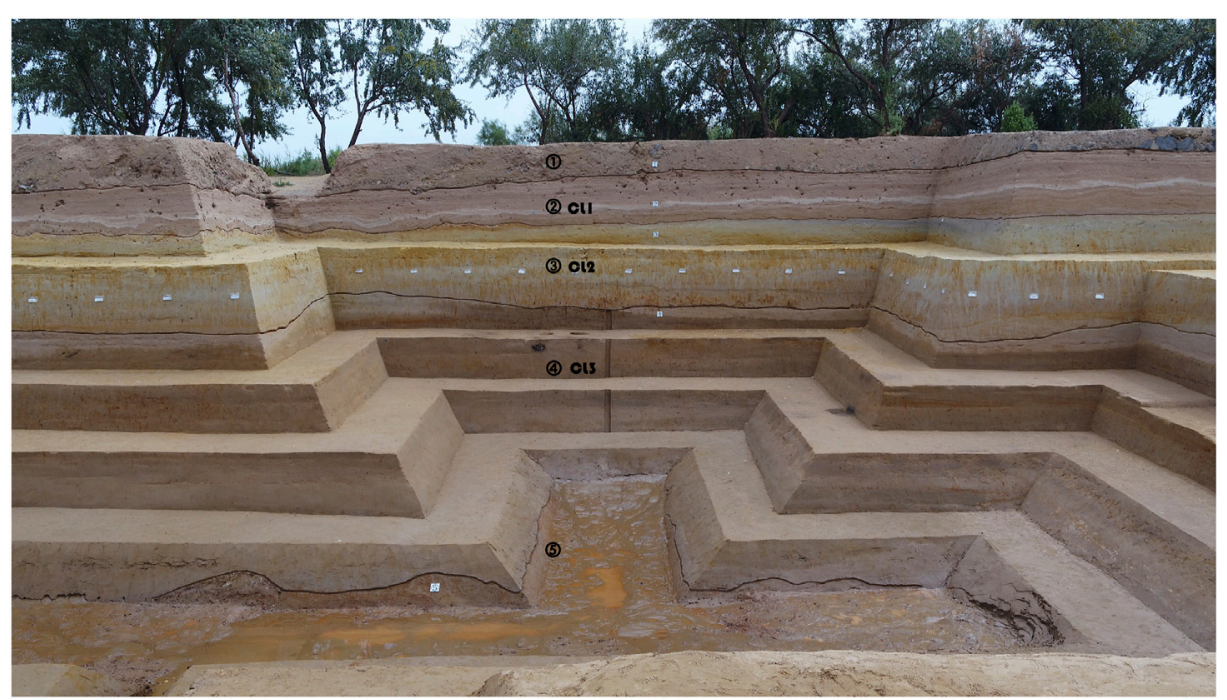

FIGURE 1 | (A) Location of QG10 (Qingtongxia City, Ningxia Hui Autonomous Region of China; (B) Stratigraphy indicating the geological layers (1-5) and archaeological horizons (CL1-CL3) (after Guan et al., 2020).

covers $c .300 \mathrm{~m}^{2}$ and reaches a depth of $c .9 .5 \mathrm{~m}$ (Peng et al., 2017; Han, 2021).

The QG10 stratigraphic sequence comprises five geological layers numbered from 1 on top to 5 in the bottom (Figure 1). Three archaeological horizons were identified, respectively in layer 2, 3 and 4; those horizons were named CL1 on top, CL2 in the middle and CL3 at bottom. CL3 yielded the richest archaeological assemblage, including the perforated red deer canine which is reported here (Figure 2). During the excavation, sediments were carefully removed using rounded-tip hand trowel and sieved with a 1-mm mesh. Larger specimens unearthed in situ were piece-plotted, while items retrieved from the sieving were recorded with information on their square meter of origin, spit and date of the excavation. Results from OSL dating and radiocarbon dating indicate the formation of CL3 occurred between 13,746 and 12,117 cal BP (Peng et al., 2017; Han, 2021).

More than 10,000 lithic remains were recovered in CL3. They fit the definition of the Chinese Late Pleistocene microlithic industry. Other cultural remains include OESBs, formal bone tools, grinding stones, hearths and post holes (Peng et al., 2017). Plant starch residue analysis suggests the QG10 visitors exploited several edible plant resources including cereals, legumes, nuts and underground storage organs (Guan et al., 2020). More than 2,000 animal remains were unearthed from CL3. In decreasing order of frequency, herbivores are represented by Equus przewalskyi, Procapra przewalskii and Cervus sp. Small mammals are mainly restricted to Lepus sp., and carnivores are dominated by Vulpes sp. (Zhang et al., 2019). A limited number of avian remains has also been identified in the faunal assemblage. 


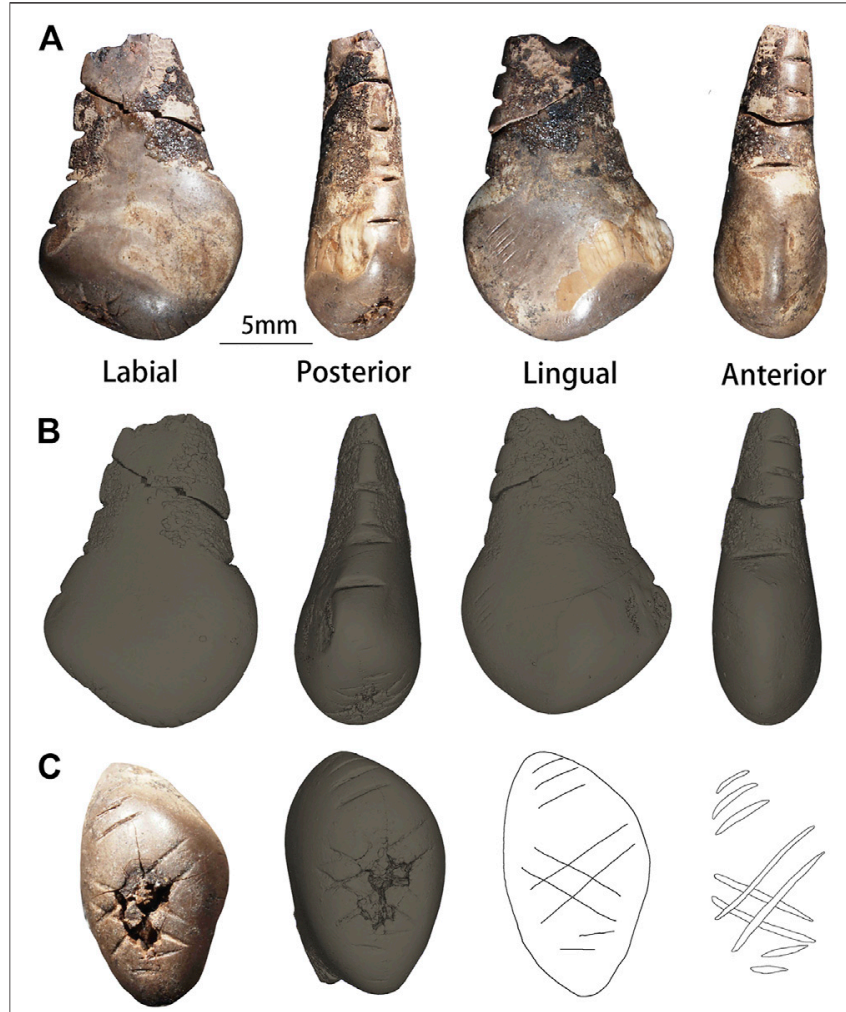

FIGURE 2 | Photographs and $\mu$-CT surface view of the aspects of the QG10 perforated red deer canine. (A) (B) From left to right: the labial, posterior, lingual and anterior aspect [(A): photographs; (B): micro-CT 3D models]; (C) The occlusal aspect (from left to right: photograph, 3D model, and tracings). Scale: $5 \mathrm{~mm}$.

Preliminary taphonomic analysis suggests humans were the main agent responsible for the accumulation and modification of the faunal remains at QG10 (Zhang et al., 2019). It appears that hunter-gatherers transported complete carcasses to process them at the site. Evidence of middle- and large-sized mammal butchery and bone fracturing for marrow exploitation is common and includes numerous cut marks on limb bones as well as a high degree of fragmentation of marrow-rich bones. In addition to their nutritional value, small animal osseous remains appear to having been targeted for the manufacture of tools (Zhang et al., 2019). The tooth described here was retrieved from the sieved sediments of CL3.

\subsection{Methods}

The QG10 perforated tooth analyzed here is curated at the Institute of Vertebrate Paleontology and Paleoanthropology (IVPP), in Beijing, China. In compliance with relevant regulations, no permits were required to conduct the analysis. Our study combines three types of data: 1) zooarchaeological data on the species and element used to manufacture the personal ornament; 2) experimental, technological and use wear data to establish how the skeletal element was procured, transformed into ornament, and worn; 3 ) sediment and residue chemical data to characterize the composition of the red and black residue still adhering to the object.

\subsubsection{Species, Sex and Age Determination}

The taxonomic identification and the side of the tooth was conducted by comparing the artifact with modern reference collections curated at the IVPP and at the Institute of Cultural Heritage, Shandong University, Qingdao, and by referring to published anatomical descriptions (Greer and Yeager, 1967; d'Errico and Vanhaeren, 2002). Sex and age determination were based on criteria available in the literature (Greer and Yeager, 1967; d'Errico and Vanhaeren, 2002; Giering, 2018). Specifically, the sex of the animal was established based on 1) the morphology of the tooth and 2) the root width/thickness ratio (d'Errico and Vanhaeren, 2002). Owing to the absence of a complete root, the age of the animal was based on qualitative features, i.e., the stage of occlusal wear and the presence of the disto-linguo-cervical lobe on the crown (d'Errico and Vanhaeren, 2002). Throughout the text, the tooth is described by its anatomical nomenclature (Hillson, 2005; White and Folkens, 2005). Metric data was collected using a digital caliper and rounding the number to $0.01 \mathrm{~mm}$; they include the maximum length, width, and thickness of the object as well as the root width and thickness.

\subsubsection{Technological and Use Wear Analyses}

The archaeological specimen was observed under microscope with a Nikon SMZ1500 stereomicroscope equipped with a Nikon CoolPix 900 digital camera at magnification ranging between 7.5-112.5x. The anthropogenic modifications observed on the tooth were identified based on criteria established in the literature (Shipman and Rose, 1983; Bromage and Boyde, 1984; d'Errico, 1995; Dominguez-Rodrigo et al., 2009; Fritz, 2009; Zhanyang Li et al., 2019). Four types of modification were distinguished: 1) set of subparallel striations; 2) single-stroke incisions made by the unidirectional displacement of a lithic tool on the surface of the tooth; 3) multiple-stroke incisions made by the repeated unidirectional displacement of a lithic tool on the surface of the tooth; and, 4) multiple-stroke notches produced by a to-andfro movement of a lithic tool on the surface (d'Errico, 2009; Rodríguez-Vidal et al., 2014).

To better test how the incisions were produced, experiments were conducted at the IVPP, and results were compared with descriptions of experimental and archaeological specimens (d'Errico, 1991; d'Errico, 1995; d'Errico, 1998; d'Errico, 2009; Fritz, 2009; Majkić et al., 2017; d'Errico et al., 2018a). Experimental notches and incisions were made using retouched and unretouched lithic tools. Three techniques were replicated, i.e., single- and multiple-stroke unidirectional incision, to-and-fro incision, on selected faunal remains, i.e., six racoon canines, four red deer incisors and a red deer ulna. The experimental specimens were coated with goldpalladium under vacuum and then observed and photographed with a Zeiss MA EVO25 Scanning Electron Microscope housed at IVPP in low vacuum mode by using an accelerating voltage of $15 \mathrm{kV}$. 
The qualitative data recorded for each notch and/or incision includes: the position of the starting and ending ends; the shape of the outline and section; presence of steps on the walls of the incision; presence of internal and/or side striations. The starting and ending points of single-stroke incisions, or multiple-stroke unidirectional incisions, are easily distinguishable from morphological features. When the tool comes into contact with the surface, it creates a "head" with clean edges, while the decreasing pressure exerted by the engraver toward the end of the movement usually generates a shallower "tail" end (d'Errico, 1989; Marshack and d'Errico, 1989; Fritz, 2009; Henshilwood et al., 2009; Majkić et al., 2018). When a notch is produced by a toand-fro movement, its shape, section, and the morphology, depth and orientation of the last micro-striation may be used to established the ending end; it is, however, impossible to establish the starting end owing to the obliteration of this information in the notching process (Fritz, 2009; RodríguezVidal et al., 2014; d'Errico et al., 2018a).

A 3D model reconstruction was obtained by scanning the tooth with a GE v|tome|x m300\&180 micro-computedtomography scanner (GE Measurement and Control, Wuntsdorf, Germany), housed at the Key Laboratory of Vertebrate Evolution and Human Origin of Chinese Academy of Sciences, Beijing. The acquisition was carried out with a $180 \mathrm{kV}$ nanofocus tube and the following beam parameters: $110 \mathrm{kV}$ and $140 \mu \mathrm{A}$. The resolution of the cubic voxel is $8.383 \mu \mathrm{m}$. Two frames per projection were acquired at a time interval of $1,000 \mathrm{~ms}$. A total of 1,800 projections were taken at $360^{\circ}$. The reconstruction of the 3D model was done with VGstudio3.5 Max software and measurements were collected with GOM 2016 software on the reconstructed model. These measurements include the angle and the maximum length, width, and depth of the notches and incisions present on the tooth, their orientation relative to the main axis of the tooth, the distance between each notch or incision belonging to the same set, and the maximum and minimum radius of the perforation.

The technique used to perforate the tooth was established based on criteria proposed by Werner and Miller (2018) and Yang et al. (2018). Morphometric and technological attributes recorded for the perforation include the position of the perforation relative to the root's width, i.e., at the center, towards the lingual or labial aspect, the presence of concentric striations on the wall of the perforation, as well as the presence and location of a use wear polish. This data was compared with the literature to established how the ornament was worn (Vanhaeren and d'Errico, 2002; Vanhaeren and d'Errico, 2003; Vanhaeren and d'Errico, 2005; Vanhaeren and d'Errico, 2017; Rigaud, 2011; Wei et al., 2017).

\subsubsection{Residue Analysis}

Observation of the archaeological specimen under microscope revealed the presence of sediments as well as red and black residues still adhering to the object. Red residues were concentrated around the perforation while the black ones were present on the root of the specimen. Samples were collected under a reflected light microscope using single-use sterilized scalpels. Red residues were sampled from two small areas near the perforation. A further four samples were collected for comparison from areas covered with sediments that appeared to lack red residues. Finally, two small samples adhering to the root were also collected, i.e., one of the black residues and one of sediments apparently lacking black residues.

Red residues and the associated control samples were analyzed by Raman and laser-induced breakdown spectroscopy (LIBS). Raman analysis was performed with a HORIBA LabRAM HR Evolution housed at the University of Science and Technology, Beijing. The samples were analyzed with an excitation wavelength of $532 \mathrm{~nm}$ at $2 \mathrm{~mW}$ laser power, using a $1800 \mathrm{gr} / \mathrm{mm}$ grating and an integration time of $10 \mathrm{~s}$ and 2 co-additions. The spectrometer worked in a spectral range from 100 to $4,000 \mathrm{~cm}^{-1}$, with a spectral resolution of $0.67 \mathrm{~cm}^{-1}$. Data were collected with LabSpec 6 software (HORIBA) and processed with OriginPro 2016. The mineral identification was based on comparison of the acquired spectra with the online spectra library available at https://rruff.info (RRUFF ID: X050102, mineral hematite from Michigan, United States). LIBS analyses were performed using a J200 LIBIEC 6 system (Applied Spectra Inc., Fremont, CA, United States) housed at the IVPP. The laser ablation was done with a $1,064 \mathrm{~nm} \mathrm{Nd:YAG} \mathrm{laser} \mathrm{operated} \mathrm{at} \mathrm{a} \mathrm{frequency} \mathrm{of}$ $20 \mathrm{~Hz}$ for a duration inferior to $7 \mathrm{~ns}$. The laser pulse energy obtained by the sample was $50 \mathrm{~mJ}$ over a spot size of $80 \mu \mathrm{m}$. The plasma emission from the sample was collected and analyzed using an AvaSpec-ULS2048 spectrometer (Avantes, Netherlands) equipped with six CCD detectors. The gate delay for the experiments varied from $50 \mathrm{~ns}$ to $1 \mathrm{~ms}$. Within one measurement, the LIBS spectra combined data from 20 laser shots to improve the signal-to-noise ratio. Elemental identification was established by comparing the spectra with data included in the TruLIBS database provided in the Aurora software (Axiom 2.1, Applied Spectra, Fremont, CA, United States).

Black residues and the associated control sample were analyzed by SEM-EDS. Samples were analyzed with the Zeiss MA EVO25 Scanning Electron Microscope housed at IVPP in low vacuum mode using an accelerating voltage of $15 \mathrm{kV}$. Backscattered electron images were collected with a HDBSD detector. EDS spectra were obtained with an Oxford X-act detector. Each sample for the EDS analyses was observed under magnifications ranging from $100 \mathrm{X}$ to $150 \mathrm{X}$. The working distance was kept constant at $8 \mathrm{~mm}$ and acquisition time was set up to $60 \mathrm{~s}$ for each EDS spectrum.

\section{RESULTS}

The tooth reported here measures $16.4 \mathrm{~mm}$ in length, $11.1 \mathrm{~mm}$ in width and $6 \mathrm{~mm}$ in thickness. The root apex is missing and only a small portion of the perforation remains. Both the left and right sides of the perforation display recent fractures, which suggests this damage occurred either during the recovery or the curation of the object. On each side of the root, a series of notches can be observed. On the occlusal surface, the tooth bears three sets of incisions. The first consists of four incisions making a hashtag pattern. The second and the third are found on either sides of the hashtag pattern and respectively correspond to three subparallel incisions on the 


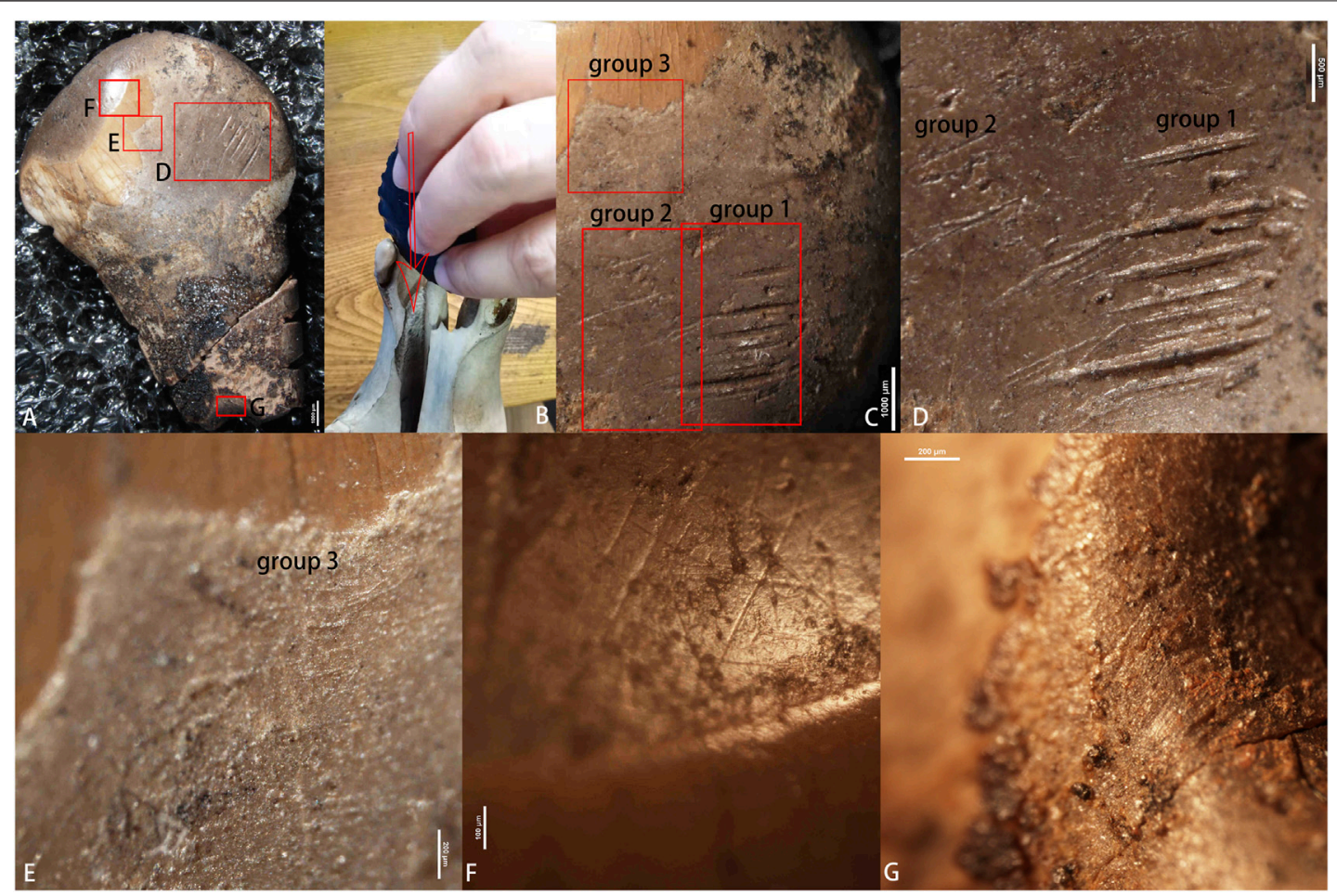

FIGURE 3 | (A) Location of the polish, scraping and possible use-wear; (B) Imitation of how scraping was produced on lingual surface of the canine; (C) Location of three subgroups of the scraping; (D,E) Close-up view of the scraping; (F) Intense polish associated with multidirectional thin striations on the occlusal surface; (G) Extremely thin striations at the periphery of the perforation. Scales: (A,C) $1,000 \mu \mathrm{m}$, (D) $500 \mu \mathrm{m}, \mathbf{( E , G ) ~} 200 \mu \mathrm{m}$; (F) $100 \mu \mathrm{m}$.

surface that connects the anterior and occlusal aspects and two subparallel incisions on the surface that connects the posterior and occlusal aspects. Black residues are preserved on the surface of the root, while red residues are restricted to areas on the margins of the perforation (Figure 2).

\subsection{Taxonomic, Sex and Age Determination}

Comparison with reference collections indicate the tooth belonged to a red deer. Based on its morphological characteristics, i.e., a nearly rectangular crown, a V-shaped root, and remnants of the disto-linguo-cervical lobe, it can safely be attributed to a right upper canine of an adult hind (Greer and Yeager, 1967; d'Errico and Vanhaeren, 2002). The sex determination of the individual is further supported by the root width/thickness ratio that is lower than 2, i.e., $7.9 \mathrm{~mm}$ in width and $4.5 \mathrm{~mm}$ in thickness (d'Errico and Vanhaeren, 2002). Owing to the fragmentary state of the tooth which prevents to record the tooth actual length, it is not possible to determine the precise age of the hind using regression equation (d'Errico and Vanhaeren, 2002). Nonetheless, an occlusal wear facet is clearly visible on the crown albeit not yet extending to the crown edges, and the DLCL is mostly preserved. Based on modern reference collections documented by d'Errico and Vanhaeren (2002), this combination of features is usually observed in hinds aged between 6 and 11 years-old.

\subsection{Technological Analysis}

The technological analysis reported here aims to document the main issues: 1) how the tooth was procured; 2) what techniques were used to make the perforation; 3) through which process was the decoration achieved; and, 4) how was the pendant worn.

\subsubsection{Tooth Procurement}

On the lingual aspect of the tooth, between the crown and the root, three clusters of scraping marks are present in the form of sub-parallel-more or less superficial-striations (Figure 3A). Their micro-morphology, i.e., V-shaped with internal and side striations, indicates they were produced by the edge of a retouched lithic tool. Judging from the location of the incisions' tail end, the tool repeatedly got into contact with the tooth while the butcher cut through soft tissues along the maxillary main axis, i.e., from the anterior to the posterior aspect of the tooth (Figure 3B). The scraping marks are deeper toward the root of the tooth than toward the occlusal surface (Figures 3C,D,E). The presence of these scraping marks on the lingual aspect of the tooth suggests the skeletal element was extracted from a recently hunted hind rather than collected from a carcass. Indeed, heads of dead red deer tend to quickly lose their canines as the gingival cuff and periodontal ligaments decay. The scraping marks indicate the gingival cuff was sufficiently fresh to maintain the root in its 


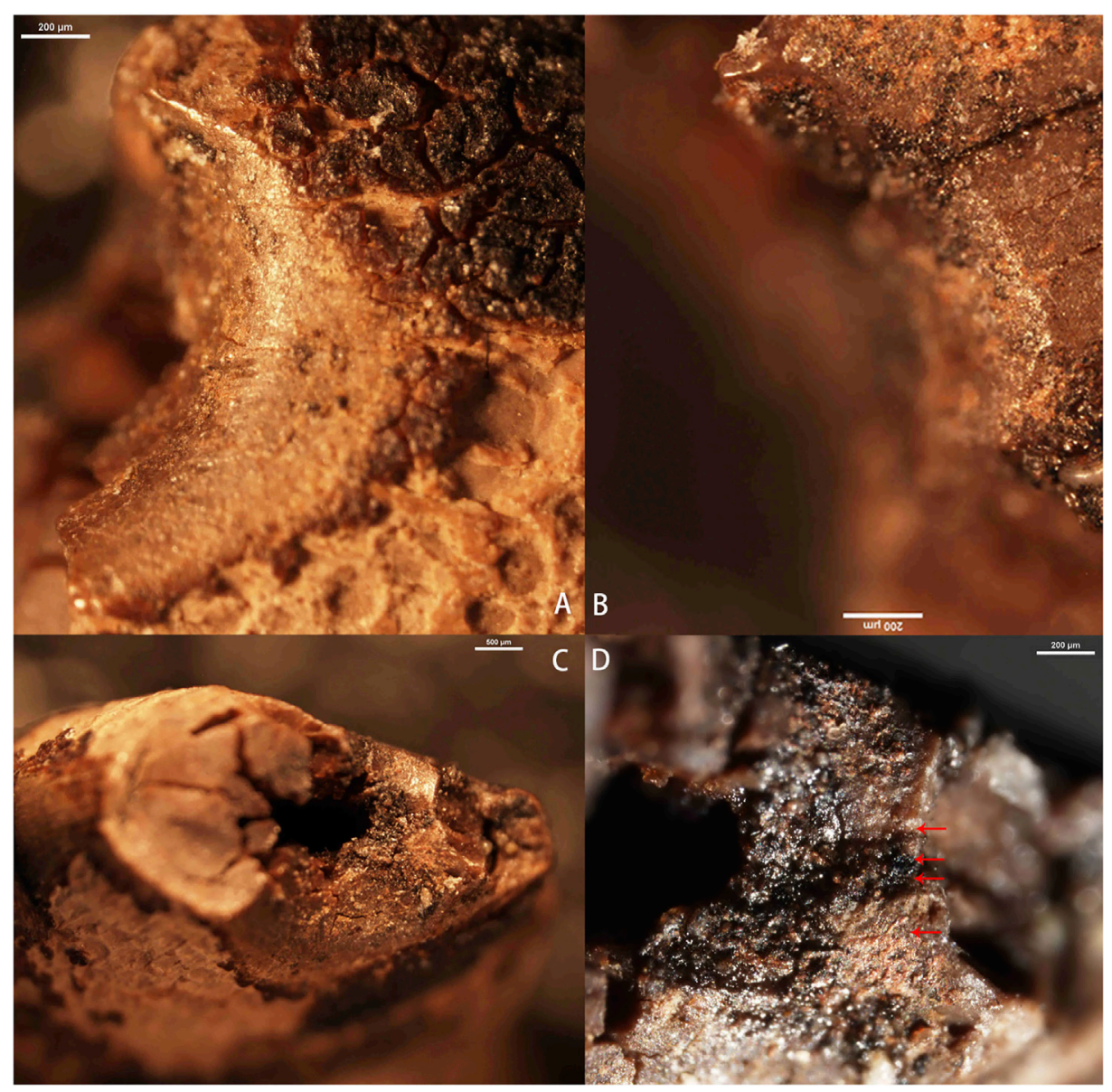

FIGURE 4 | (A) Conical perforation on the lingual surface; (B) Conical perforation on the labial surface; (C) Remaining part of the broken perforation; (D) Concentric striations in the middle part of the perforation surface. Scales: (A,B,D) $200 \mu \mathrm{m}$, (C) $500 \mu \mathrm{m}$.

funnel-shaped cavity and needed cutting for the tooth to be removed (for a similar behavior from the Aven des Iboussières hunters, see d'Errico and Vanhaeren, 2002).

\subsubsection{Perforation Technique}

Most of the perforation is missing owing to a recent fracture; approximately a quarter of the circumference is still intact. The remaining perforation features provide sufficient clues to establish its manufacturing techniques (Figure 4C). The hole is biconical in cross-section. The opening on the lingual aspect is more flared than the one on the labial aspect (Figures 4A,B). Their respective maximum radius is 1.51 and $0.89 \mathrm{~mm}$; the radius at the junction of the two cones is $0.77 \mathrm{~mm}$. In cross-section, the perforation originating from the lingual surface extends to more than three quarter of the root thickness. The perforation was most likely round in shape. Its walls are smooth and even; no irregularities can be seen on what remains from it. Most of the perforation walls and edges are smoothed (see Section 3.2.4 Use wear below). Only a few concentric striations in the middle part of the perforation can be observed (Figure 4D). No superficial striations were observed on the edges of the perforation; some may be covered by the residues present around it but their removal was not attempted.

Based on the aforementioned observations, it appears the tooth was perforated with a conical-shaped lithic drill. The ornament maker likely positions the tooth with its labial aspect facing the ground to make the perforation in the middle of the root. Facing this aspect to the ground would have eased the initial stages of the process as it is flatter. Indeed, the concave outline of the lingual aspect would have provided a less stable surface to apply force onto the tooth while drilling and increased the chance of breaking the root in the process (Gwinnett and Gorelick 1991). Given the outline of the perforation, the drill bit appears to have made full rotations rather than partial ones. This motion can only be achieved if the lithic implement was hafted on a composite tool instead of being hand-held (Werner and Miller, 2018; Yang et al., 2018). When the perforation opening became visible on the labial aspect, the maker turned the tooth around and enlarged the newly created hole with the same technique. 

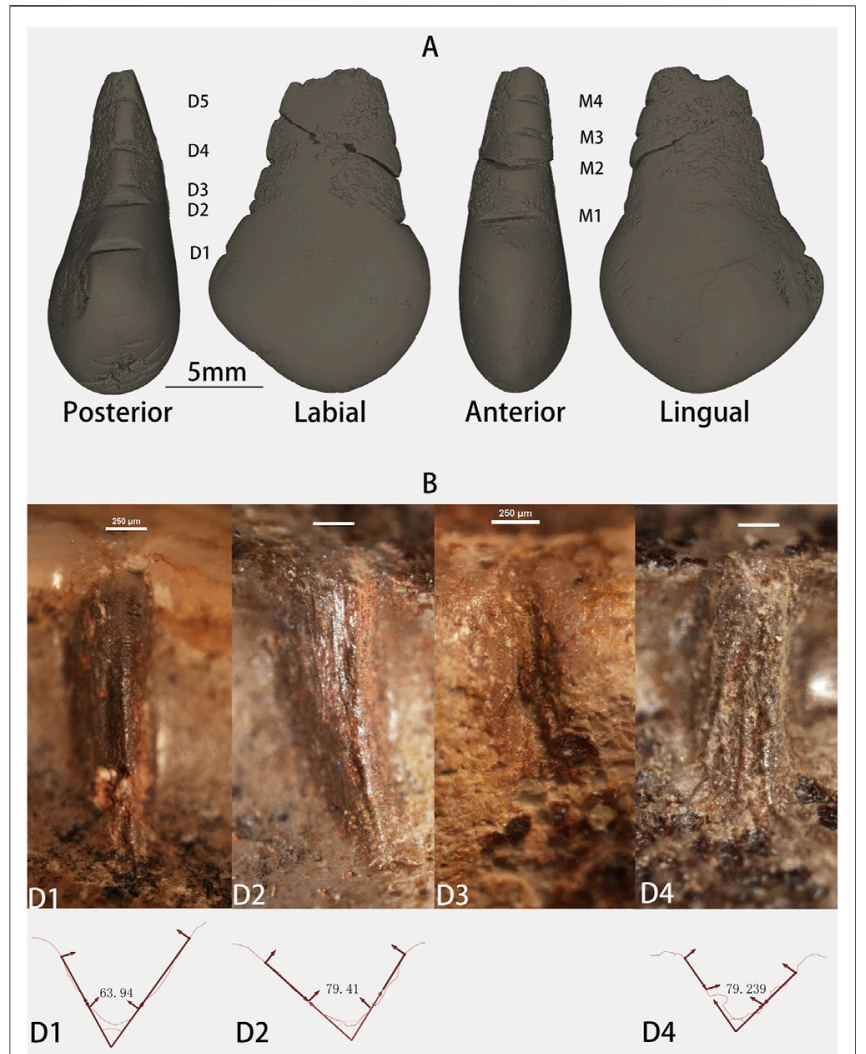

D2

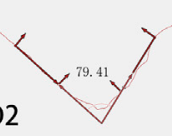

C
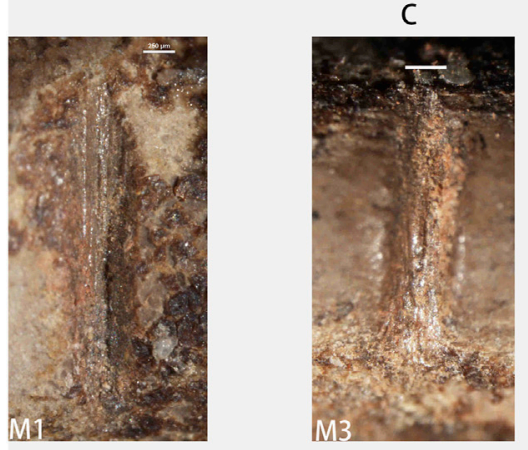

M3

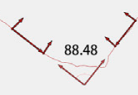

D4
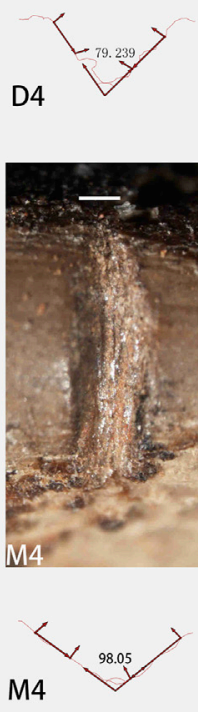

M1

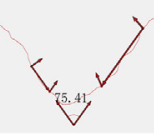

FIGURE 5 | (A) Location of the notches on the QG10 perforated tooth; (B) Notches on the posterior aspect and their cross-sections with measured angles (); (C) Notches on the anterior aspect and their cross-sections with measured angles (). Scales: (A) $5 \mathrm{~mm}$, (B,C) $250 \mu \mathrm{m}$.

\subsubsection{Decoration Techniques}

The QG10 perforated red deer canine bears a decoration consisting of five sets of notches and incision. A series of five and four notches is visible respectively on the posterior and anterior aspect of the tooth. A fracture propagates obliquely on the root from the fifth notch on the posterior aspect (notch D5, Figure 2 and Figure 5) to the second notch

on the anterior aspect (notch M2, Figure 2 and Figure 5), respectively, therefore preventing their complete description.

The notches are short and, with the exception of D3, deep. Their cross-section is V-shaped, their walls lack any distinct steps and they all exhibit a rounded end and a fringed one on the opposite end (Figures 5B,C). Comparison with the notches produced experimentally in the present study (Figures 6A-F) and those published in the literature indicates they were produced by the repeated unidirectional sliding of an unretouched lithic edge on the surface of the tooth (Fritz, 2009; Rodríguez-Vidal et al., 2014; d'Errico et al., 2018a).

The notches on the posterior aspect of the tooth share a number of characteristics that allows to infer the sequence in which they were produced. The ends located toward the lingual aspect of the tooth are fairly round while the opposite ends, i.e., toward the labial aspect, are fringed and often end in a tail pointing toward the root apex. This combination suggests the notching motion was initiated from the lingual aspect of the tooth and ended toward the labial aspect. The further away from the crown and closer to the root apex the notch is, the thicker and coarser the striations within the notches become. This observation holds as well for D3, which presents striations coarser than D2 but thinner than D4. Interestingly, whenever this information is available, the angle of the notches wall also increases for notches located closer to the root apex compare to those located near the crown (Table 1). Considering the maker of this decoration likely used an unretouched lithic tool, it seems reasonable to suggest the first notch was made on the root near the crown and each following notch closer to the root in a single session, perhaps with the same tool. In the process, the micro-chipping of the lithic edge would have resulted in the production of wider notches and produced coarser striations within the notches. When considering the juxtaposition of notches from the crown to the root apex as well as the beginning and end points of the movement, it would appear the person who made this set was right-handed (d'Errico, 1992; d'Errico et al., 2018a). If this is the case, the person would have initiated the notch D3 but interrupted in the middle of the process, perhaps because he/she considered it was too closed to notch D2 (Table 2).

A broadly similar pattern is observed for the series of notches on the anterior aspect of the tooth. They too were produced by the repeated unidirectional displacement of an unretouched lithic edge on the root. Judging from the position of the tail end pointing toward the root apex, the gesture was initiated from the labial aspect and ended toward the lingual aspect of the tooth. The striations within notches M1-M4 become coarser the closer when get near the root apex. Similarly, the angle of the notch walls also increases for notches located closer to the root apex (Table 1). As it was the case for the previous series of notches, this one also appears to have been produced in a single session, starting from the crown and moving toward the root apex by a right-handed individual.

A close comparison between the two sets of notches suggests the all nine notches were made in a single session. There is a clear continuum in the value for the angle of the notches' walls and the 


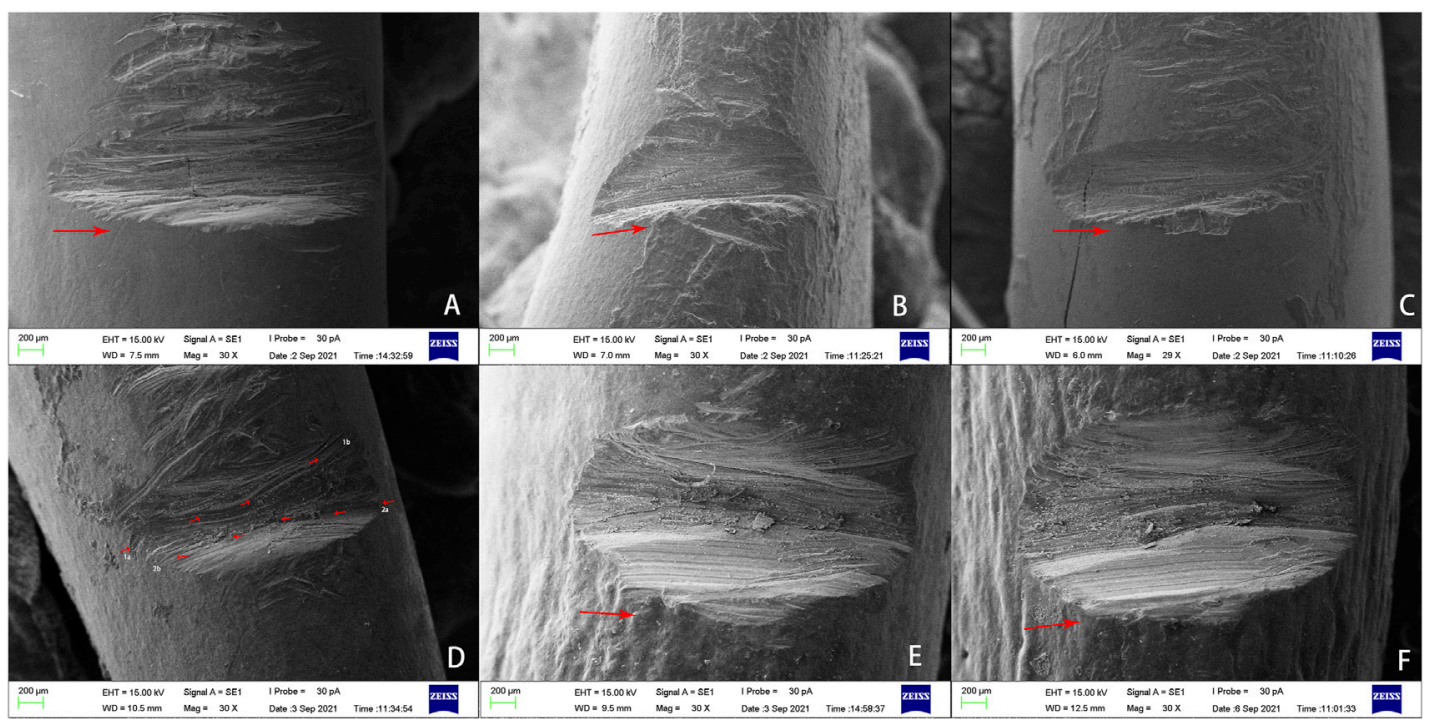

FIGURE 6 | SEM micrographs of the experimentally produced notches. (A,B,C) Notches made by repeatedly passing an unretouched flake into the grooves in the same direction (arrows indicate the direction of the movement); (D) Notch produced by a to-and-fro movement of an unretouched flake; notice the different orientations of the striations; (E,F) Notches made by repeatedly passing a bifacially retouched flake into the grooves in the same direction (arrows indicate the direction of the movement). Notice the U-shaped cross-section and the presence of multiple steps on the fracture walls. Scales: $200 \mu \mathrm{m}$.

TABLE 1 | Morphometric and technological data on the notches incised on the QG10 perforated red deer tooth.

\begin{tabular}{|c|c|c|c|c|c|c|c|c|c|c|c|c|c|}
\hline $\begin{array}{l}\text { Notch } \\
\text { Position }\end{array}$ & No. & $\begin{array}{c}\text { Head } \\
\text { Location }\end{array}$ & $\begin{array}{c}\text { Tail } \\
\text { Location }\end{array}$ & Section & Shape & Step & $\begin{array}{l}\text { Internal } \\
\text { striation }\end{array}$ & $\begin{array}{c}\text { Side } \\
\text { striation }\end{array}$ & $\begin{array}{l}\text { Length } \\
\text { (mm) }\end{array}$ & $\begin{array}{c}\text { Mid } \\
\text { width } \\
(\mathrm{mm})\end{array}$ & $\begin{array}{c}\text { Depth } \\
\text { (mm) }\end{array}$ & $\begin{array}{l}\text { Orientation } \\
\text { relative } \\
\text { to the } \\
\text { main } \\
\text { axis }\end{array}$ & $\begin{array}{c}\text { Angle } \\
\text { of the } \\
\text { notch's } \\
\text { wall }\end{array}$ \\
\hline Anterior & M1 & Labial & Lingual & SY & V & No & Yes & No & 2.722 & 0.562 & 0.306 & $85.12^{\circ}$ & $75.41^{\circ}$ \\
\hline Anterior & M2 & NA & NA & NA & NA & NA & NA & NA & NA & NA & NA & $85.33^{\circ}$ & NA \\
\hline Anterior & M3 & Labial & Lingual & SY & V & No & Yes & No & 1.901 & 0.577 & 0.272 & $89.98^{\circ}$ & $88.48^{\circ}$ \\
\hline Anterior & M4 & Labial & Lingual & SY & V & No & Yes & No & 1.779 & 0.606 & 0.261 & $92.68^{\circ}$ & $98.05^{\circ}$ \\
\hline Posterior & D1 & Lingual & Labial & SY & V & No & Yes & No & 2.166 & 0.58 & 0.336 & $94.93^{\circ}$ & $63.938^{\circ}$ \\
\hline Posterior & D2 & Lingual & Labial & SY & V & No & Yes & No & 2.238 & 0.783 & 0.346 & $86.31^{\circ}$ & $79.41^{\circ}$ \\
\hline Posterior & D3 & Lingual & Labial & SY & V & No & Yes & No & 1.108 & 0.496 & 0.153 & $90.28^{\circ}$ & NA \\
\hline Posterior & D4 & Lingual & Labial & SY & V & No & Yes & No & 1.681 & 0.758 & 0.412 & $83.43^{\circ}$ & $79.239^{\circ}$ \\
\hline Posterior & D5 & NA & NA & NA & $\mathrm{NA}$ & NA & NA & NA & NA & NA & NA & $88.71^{\circ}$ & NA \\
\hline
\end{tabular}

SY, symmetrical; V, V-shaped; NA, not available.

striations within the notches gradually become coarser from D1 to D5 and then from M1 to M4. This pattern indicates the individual started by making notches on the posterior aspect of the root, then flipped the tooth along its long axis to produce the second set, both times making the first notch close to the crown and gradually moving toward the root apex, while attempting to space them more or less regularly (Table 2).

On the occlusal aspect of the perforated tooth, three sets of deep incisions are distinguished. The first is composed of four incisions making a hashtag pattern (L1-L4; Figure 2 and Figures $7 \mathbf{A}, \mathbf{B}, \mathbf{C})$. On either side of this pattern, a set of three and two subparallel incisions are present, respectively, on the surfaces that connect the anterior (L5-L7; Figure 2 and Figures 7B,D) and posterior (L8 and L9; Figure 2 and Figures $7 \mathbf{B}, \mathbf{E})$ aspects to the occlusal aspect.

The incisions L1 and L2 are parallel to one another while L3 and L4 are slightly converging toward the lingual aspect of the tooth. The middle part of the hashtag pattern is partly missing owing to the thinning of the enamel in the center of the occlusal surface and exposure of the pulp cavity. Presence of sediments within the cavity and weathered fractures suggests an ancient origin of this damage. However, recent micro-fractures indicate the damage may have been slightly expanded during the recovery of the tooth and its curation. Each pair is obliquely crossing the 
TABLE 2 | Distance between the adjacent notches incised on the QG10 perforated red deer tooth.

\begin{tabular}{lcc} 
& $\begin{array}{c}\text { Bottom distance between } \\
\text { adjacent notches } \mathbf{( m m )}\end{array}$ & $\begin{array}{c}\text { Top distance between } \\
\text { adjacent notches } \mathbf{( m m})\end{array}$ \\
\hline D1-D2 & 2.55 & 1.864 \\
D2-D3 & 0.897 & 0.328 \\
D2-D4 & 3.069 & 2.314 \\
D3- D4 & 2.337 & 1.516 \\
D4-D5 & 2.645 & 2.016 \\
M1-M2 & 2.583 & 2.138 \\
M2-M3 & 1.643 & 1.009 \\
M3-M4 & 2.041 & 1.364
\end{tabular}

occlusal surface and were produced by the displacement of a lithic tool from the labial aspect toward the lingual aspect of the tooth. Morphologically, the cross-sections of the incisions are $\mathrm{V}$-shaped and asymmetrical to the left (Table 3); they display a steep right side and an oblique left side. The termination point of the incisions flares out toward the left. Microscopically, numerous micro-striations are visible within the incisions and some are also present on the side of L1, L3 and L4. Incision L3 overlaps L1 and L2, which indicates the latter two incisions were made prior to L3. It seems reasonable to assume that L4 was likely overlapping L1 and L2 originally. The four incisions appear to having been made with a sharp lithic retouched point (Majkić et al., 2017; d'Errico et al., 2018a; Zhanyang Li et al., 2019). In addition, their similar outline, length and internal morphology suggest they were produced in a single session, most likely by a left-handed individual (d'Errico et al., 2018a; Zhanyang Li et al., 2019).

Incisions L5-L9 are fairly similar (Figures 7D,E). The movement that produced them was initiated from the lingual aspect toward the labial aspect of the tooth. Morphologically, all five incisions are somewhat U-shaped and symmetrical with their termination end flaring toward the right. Microscopically, microstriations are visible within each incision. The resemblance in the relative disposition of micro-striations within L5-L9 suggests the two sets of incisions were each made by a unidirectional stroke using the retouched edge of a lithic tool. Micro-chipping of the lithic edge could explain the small differences observed from one incision to the other. If this is the case, all five incisions would have been produced in a single session by a right-handed individual (Zhanyang Li et al., 2019).

\subsubsection{Use Wear Analysis}

The occlusal aspect of the tooth is covered with an intense polish, associated with multidirectional thin spindle-shaped striations (Figure 3F). Although a number of processes may have caused this, e.g., feeding behavior of cervids, use and manipulation of the object, post-depositional alteration, etc., it is possible, however, that the final stage of making the ornament entailed polishing it with a tanned hide, which produces similar alterations (d'Errico, 1993). Invasive polish is also observed on walls of the perforation. The presence of a tight cluster of extremely thin striations at the periphery of the perforation, oriented parallel to the long axis of the tooth
(Figure 3G and Figure 4A), indicates the possible use of a leather or sinew strap to fix the object on a garment. This intense polish completely obliterated most traces of manufacture, which suggests this object was used over a long period of time (Rigaud, 2011).

\subsubsection{Residue Analysis}

Red residues were detected on the margin of the perforation. Both the $\mu$-Raman and LIBS analyses of the sampled red residues detected Fe-rich components (Figure 8). Comparison of the $\mu$-Raman spectra with data included in the TruLIBS database confirmed the presence of hematite. The analysis of the control samples with LIBS, i.e., those apparently lacking red residues, also yielded spectra with peaks centered on $\mathrm{Fe}$ element albeit less intense than the two previous samples. This could probably be due to the presence of micro-particles of hematite in the sediment that were not visible under the microscope. Lumps of black-colored sediments were visible to the naked eye on all aspects of the root except on the two small, flat and smooth areas on the labial aspect. Their location never exceeds the cemento-enamel junction with the crown. SEM-EDS analysis of the sample reveals a $\mathrm{K}$ - $\mathrm{Ca}$ - and $\mathrm{Na}$-rich elements indicating charcoal or charred organic material. The control sample of sediments without black residues sampled on the labial aspect of the root lacks $\mathrm{K}$ and $\mathrm{Na}$ altogether but contained $\mathrm{P}$ (Figure 9, Table 4).

\section{DISCUSSION}

Since the early Upper Paleolithic, animal teeth were commonly used to manufacture personal ornaments (Wissler and Duvall, 1908; Bordreuil, 1966; Kidd, 1986; White, 1989; Newell et al., 1990; Camps-Faber, 1991; Ladier and Welté, 1994; Giacobini, 1999; Pearson, 1999; d'Errico and Vanhaeren, 2002; Grinnell, 2003; Vanhaeren and d'Errico, 2003; Vanhaeren and d'Errico, 2005; Vanhaeren and d'Errico, 2006; Kuhn and Stiner, 2007; White, 2007; Giering, 2018; Tejero et al., 2020). These items, found at numerous sites including burials (Albrethsen and Petersen, 1976; Rainio and Mannermaa, 2014; Rainio et al., 2021), were surely shaped and assembled carefully to embellish the garments of prehistoric groups. Specific codes relating to where and how personal ornaments were placed on the body could have facilitated the communication of information on the individual and group identity as well as his/her status within that group. Furthermore, the number of adornments likely signaled the individual wealth as some ethnographic accounts suggest (McCabe, 1982; O'Shea and Zvelebil, 1984).

Throughout prehistory, numerous taxa were targeted as providers of teeth considered fit for making personal ornaments. Among them, cervid canines appear to have been subject of a particular preference (Giacobini, 1999; d'Errico and Vanhaeren, 2002; Taborin, 2004; Vanhaeren and d'Errico, 2003; Vanhaeren and d'Errico, 2005; Vanhaeren and d'Errico, 2006; Fernández and Jöris, 2008; Tejero et al., 2020), perhaps owing to their rounded shape that is in stark contrast with other animal 


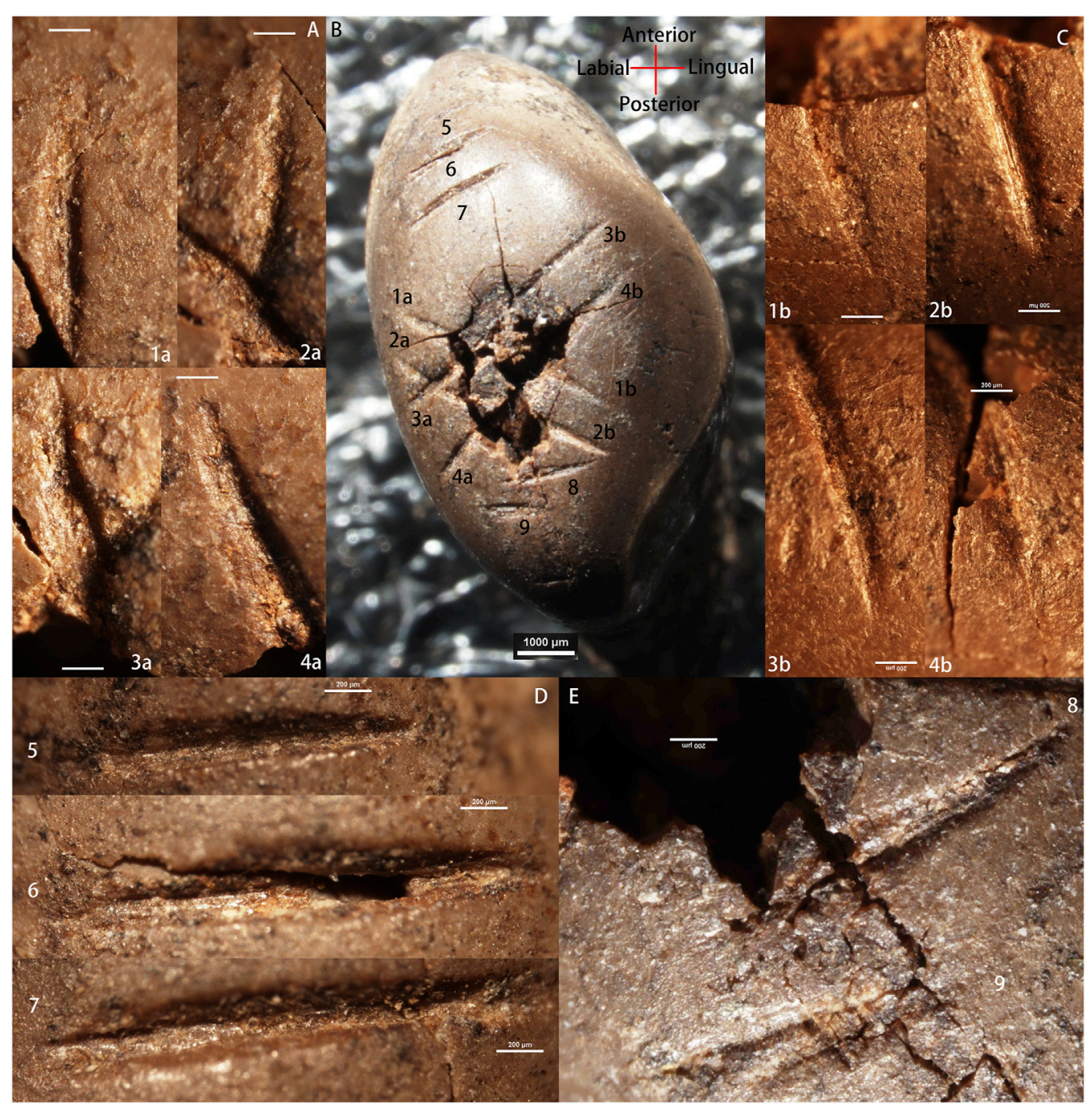

FIGURE 7 | Incisions on occlusal surface of the QG10 artifact. (A) Microphotographs of the starting points (1a-4a) for incisions L1-L4; (B) Location of the incisions; (C) Microphotographs of the end points (1b-4b) for incisions L1-L4; (D) Microphotographs of incisions L5, L6 and L7. (E) Microphotograph of incisions L8 and L9. Scales: (A,C-E) $200 \mu \mathrm{m}$; (B) 1,000 $\mu \mathrm{m}$.

teeth, e.g., carnivore canines and herbivore incisors. Although their significance in symbolic systems from the remote past is likely impossible to uncover, some historical accounts suggest they were probably used as trophies (Greer and Yeager, 1967; Barge-Mahieu and Taborin, 1991) or priced possessions associated to good health, luck (Kidder, 1957; Dubin, 1999) and longevity (Densmore, 1918; Loendorf, 2010; Giering, 2018). The peculiar place occupied by cervid canines in past symbolic systems is further supported by the occasional discoveries of personal ornaments made from other raw materials, e.g., bone, antler, ivory or stone, and transformed into shapes that mimic this skeletal element (Choyke, 2001; Vanhaeren and d'Errico, 2006; Fernández and Jöris, 2008; Giering, 2018; Tejero et al., 2020, 2021). Making a cervid canine-shaped ornament from these materials would have been a time-consuming task, and such enterprise surely highlights the important value attributed to this item that went beyond simple aesthetic considerations in past symbolic systems (Kidder, 1957; Bar-Yosef Mayer, 2020; Tejero et al., 2020).

Research on the variability of personal ornamentation practices, i.e., both the report of the ornament types and the detail description of the manufacturing process and use, is still at an incipient stage in China. Only a little more than a dozen sites yielded personal ornaments, and a handful of assemblages have been subjected to detailed analysis (Wei et al., 2016, 2017; Pitarch Martí et al., 2017; d'Errico et al., 2021). When cervid canine are concerned, only two sites had yielded such items until the present research, i.e., Zhoukoudian Upper Cave (Pei, 1939; d'Errico et al., 2021) and Xiaogushan (Huang et al., 1986). Our analysis of the QG10 perforated red deer canine contributes to documenting the technological know-hows solicited in the manufacture and use of this aspect of material culture, and providing a new outlook of the diversity in the adornment systems of the human groups that 
TABLE 3 | Morphometric and technological data on the incisions engraved on occlusal aspect of the QG10 perforated red deer tooth.

\begin{tabular}{|c|c|c|c|c|c|c|c|c|c|c|c|}
\hline No & $\begin{array}{c}\text { Start } \\
\text { Location }\end{array}$ & $\begin{array}{c}\text { End } \\
\text { Location }\end{array}$ & Section & Shape & Step & $\begin{array}{c}\text { Internal } \\
\text { str. }\end{array}$ & $\begin{array}{l}\text { Side } \\
\text { str. }\end{array}$ & $\begin{array}{l}\text { Length } \\
\text { (mm) }\end{array}$ & $\begin{array}{l}\text { Width } \\
\text { (mm) }\end{array}$ & $\begin{array}{c}\text { Depth } \\
\text { (mm) }\end{array}$ & $\begin{array}{l}\text { Orientation } \\
\text { relative } \\
\text { to the } \\
\text { tooth } \\
\text { main } \\
\text { axis }\end{array}$ \\
\hline 1 & Labial & Lingual & $\mathrm{AL}$ & V & No & Yes & Yes & 4.672 & 0.33 & 0.071 & 66.41 \\
\hline 2 & Labial & Lingual & $\mathrm{AL}$ & V & No & Yes & NA & 4.528 & 0.321 & 0.061 & 53.42 \\
\hline 3 & Labial & Lingual & $A L$ & V & No & Yes & Yes & 5.319 & 0.345 & 0.084 & 117.94 \\
\hline 4 & Labial & Lingual & $A L$ & V & No & Yes & Yes & 5.401 & 0.338 & 0.057 & 122.09 \\
\hline 5 & Lingual & Labial & SY & $U$ & Yes & Yes & No & 1.799 & 0.207 & 0.129 & 81.07 \\
\hline 6 & Lingual & Labial & SY & $U$ & Yes & Yes & No & 2.358 & 0.438 & 0.234 & 82.92 \\
\hline 7 & Lingual & Labial & SY & $U$ & Yes & Yes & No & 2.636 & 0.359 & 0.159 & 78.76 \\
\hline 8 & Lingual & Labial & SY & $U$ & Yes & Yes & No & 1.732 & 0.287 & 0.041 & 93.557 \\
\hline 9 & Lingual & Labial & SY & $U$ & Yes & Yes & No & 1.312 & 0.296 & 0.053 & 96.029 \\
\hline
\end{tabular}

$A L$, Asymmetrical to the left; SY, symmetrical; str., striations; $V, V$-shaped.

lived in arid and semi-arid regions of Northern China during the Late Glacial period.

The first step in making a personal ornament consists in acquiring the raw material. When dealing with animal teeth, it is relevant to compare the taxa selected as provider of teeth with the faunal assemblage at the site to establish whether these animal species were available in the environment. At QG10, the faunal assemblage is dominated by Lepus sp. and Equus przewalskyi followed by Procapra przewalskii, Vulpes sp., and Cervids (Jingwen Dai, 2021, personal communication). It is rather surprising to have found only a single perforated tooth in the assemblage, moreover a red deer canine, considering that foxes and horses teeth were also used to make perforated ornaments in other regions of Eurasia in the Palaeolithic (Goutas, 2004; Vanhaeren and d'Errico, 2006; d'Errico and Vanhaeren, 2015; Shunkov et al., 2020). This observation either suggests red deer teeth were preferentially targeted by members of this tradition, or that the tooth was obtained through some form of social exchange (see below). The QG10 specimen bears clear traces of scraping on its lingual aspect which suggests that, given the fast decaying process of cervid gums and periodontal soft tissues, the tooth was extracted from the maxillary of an adult female red deer shortly after it was hunted.

The second step relates to the modification of the tooth to allow its suspension on the body. After cleaning the tooth, the QG10 artisan stabilized the red deer tooth with its labial aspect facing the ground and initiated the perforation using a composite drill tipped with a lithic point. When the opening of the perforation became visible on the labial aspect of the tooth, the object was turned and the same technique was applied to enlarge the perforation and allow a thread to be inserted in it. The QG10 is the first mammal teeth ornament from Northern China perforated with a lithic point hafted onto a drill. This technique, however, was not a novelty in the technological repertoire of Late Paleolithic populations living in this vast region. Indeed, the OESBs found at the Shuidonggou site complex (Wei et al., 2016, 2017; Pitarch Martí et al., 2017) as well as some limestone beads and a pebble made of volcanic rock from Zhoukoudian Upper
Cave (Pei, 1939; d'Errico et al., 2021) were also perforated by hafted-drilling. It is worth noting that, at Zhoukoudian Upper Cave and at Xiaogushan, the perforation of mammal teeth most often entailed incising the root through a variety of techniques and regularizing the edges of the hole by hand-held rotation (d'Errico et al., 2021). It would appear that, sometime between 25 and $13 \mathrm{ka}$, changes in the technological system allowed the artisans to transfer this drilling technique to the manufacture of beads made of animal teeth. We hypothesize that this change must be searched in the lithic component of the technological system. Indeed, the generalized manufacture of microcore and microblade technology after $c .25$ ka considerably diminished the size of the lithic tools available to the Late Glacial human groups. Evidence from bone technology suggests these small implements were components of complex composite technologies (Yi et al., 2013, 2021; d'Errico et al., 2018b; Zhang et al., 2018). Hafting a microblade onto a composite drill would have therefore allowed the makers of personal ornaments to perforate the small root of the tooth in a precise and effective manner.

Establishing how the QG10 perforated red deer canine was worn is rather difficult owing to the recent fracture of the root apex. What remains from the perforation is nonetheless informative to that regard. Indeed, an invasive use wear has almost completely obliterated the micro-striations resulting from the drilling of the perforation. The location of this use wear is peculiar. If the bead was suspended on a necklace, the use wear would have developed on the opposite side of the perforation, i.e., the one that is currently missing as a result of the fracture. If the bead was fixed on clothing with nots or tied with two threads, the use wear would have developed on either side of the perforation, which are also missing. By deduction, it would appear that the QG10 tooth was fixed on the body, or garment, with its crown facing upward. However, such suspension system would likely have required to use some form of adhesive to maintain the bead in place despite the movements of its wearer. The hematite around the perforation and charcoal compound on the root may be remnants of such adhesive recipe. Glues with similar chemical composition were 

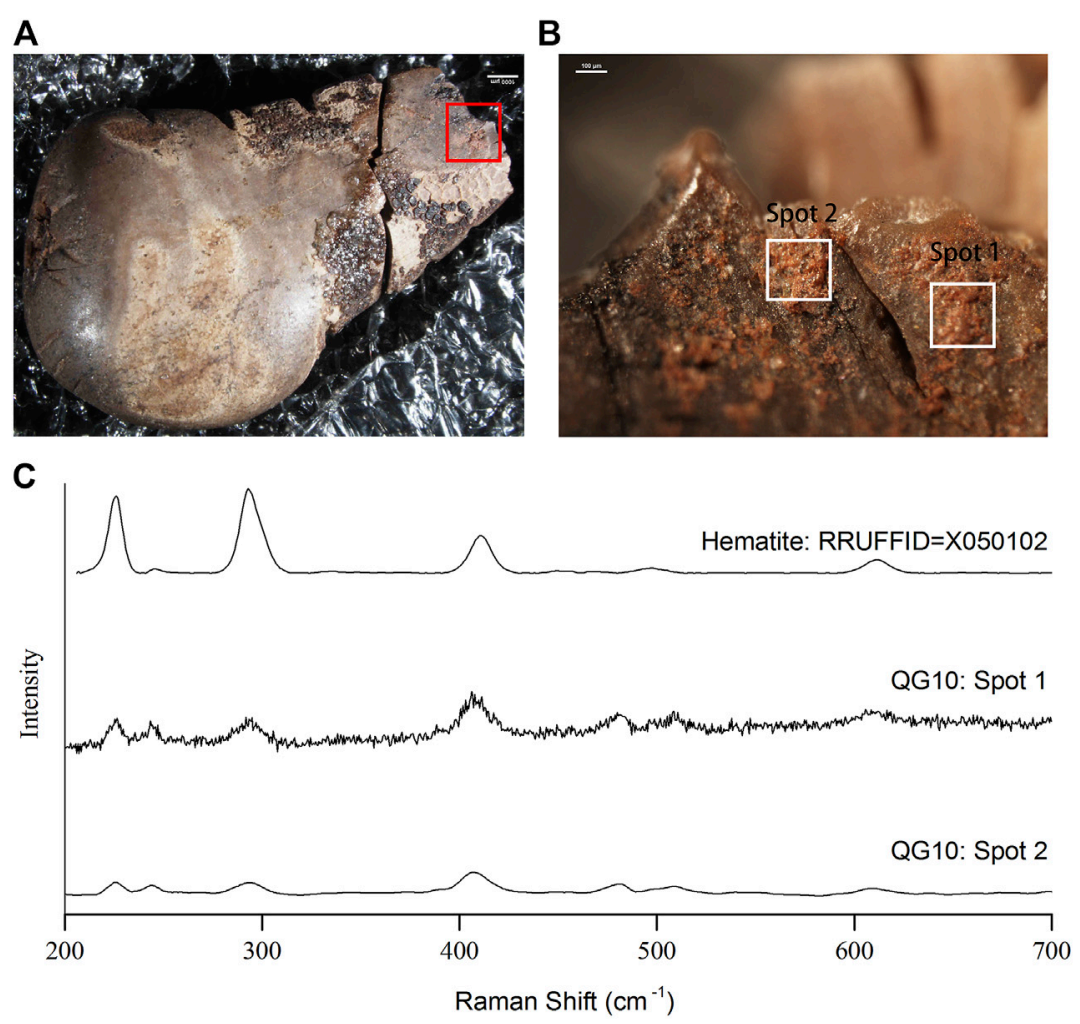

D

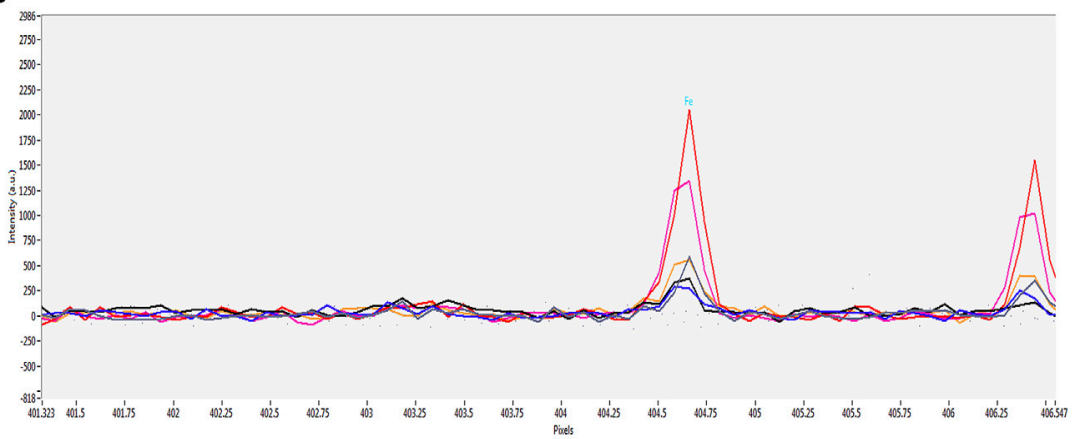

FIGURE 8 | (A) Location of the red residues on the tooth; (B) Areas in which red residues were sampled; (C) Results of the analysis of the red residues by Raman spectroscopy; (D) Results of the analysis of the red residues by LIBS (the pink and orange lines are for the two sampled spots of the red residues and other lines are for the sampled spots from areas seemingly lacking red residues). Scales: (A) 1,000 $\mu \mathrm{m}$, (B) $100 \mu \mathrm{m}$.

suggested for fixing beadworks from Serbia (Cristiani and Borić, 2012; Cristiani et al., 2014) and Germany (Rigaud, 2011; Rigaud et al., 2014). The use of red/brown adhesive compounds in beadwork has also been observed among North American Plains indigenous tribes practicing ornamental embroidery (Sturtevant, 1978; Dubin, 1999).

The technological and morphometric analysis of the decorations present on the QG10 tooth reveals surprising information on the individuals who came into contact with this object prior to its deposition. The decoration consists of two sets of notches located respectively on the anterior and posterior aspects of the root, a hashtag pattern on the middle of the occlusal aspect of the tooth bordered by two sets of respectively two and three incisions. Differences in the tools and techniques used to make the marks as well as the handedness of their makers suggest at least two, perhaps three, individuals further modified the tooth after its perforation. One left-handed individual made the hashtag pattern in a single session on the occlusal surface, and one, perhaps two, righthanded individuals made the notches on the root and the incisions that bordered the hashtag on the occlusal surface. The individual(s) who(m) made these latter markings made the notches in a single session with the same tool and the incisions with a different tool. It is not clear, however, whether the notches and incisions bordering the hashtag were made during the same session albeit with a change of tool and technique. Given the large number of Paleolithic perforated red deer canines documented in the literature, those bearing 

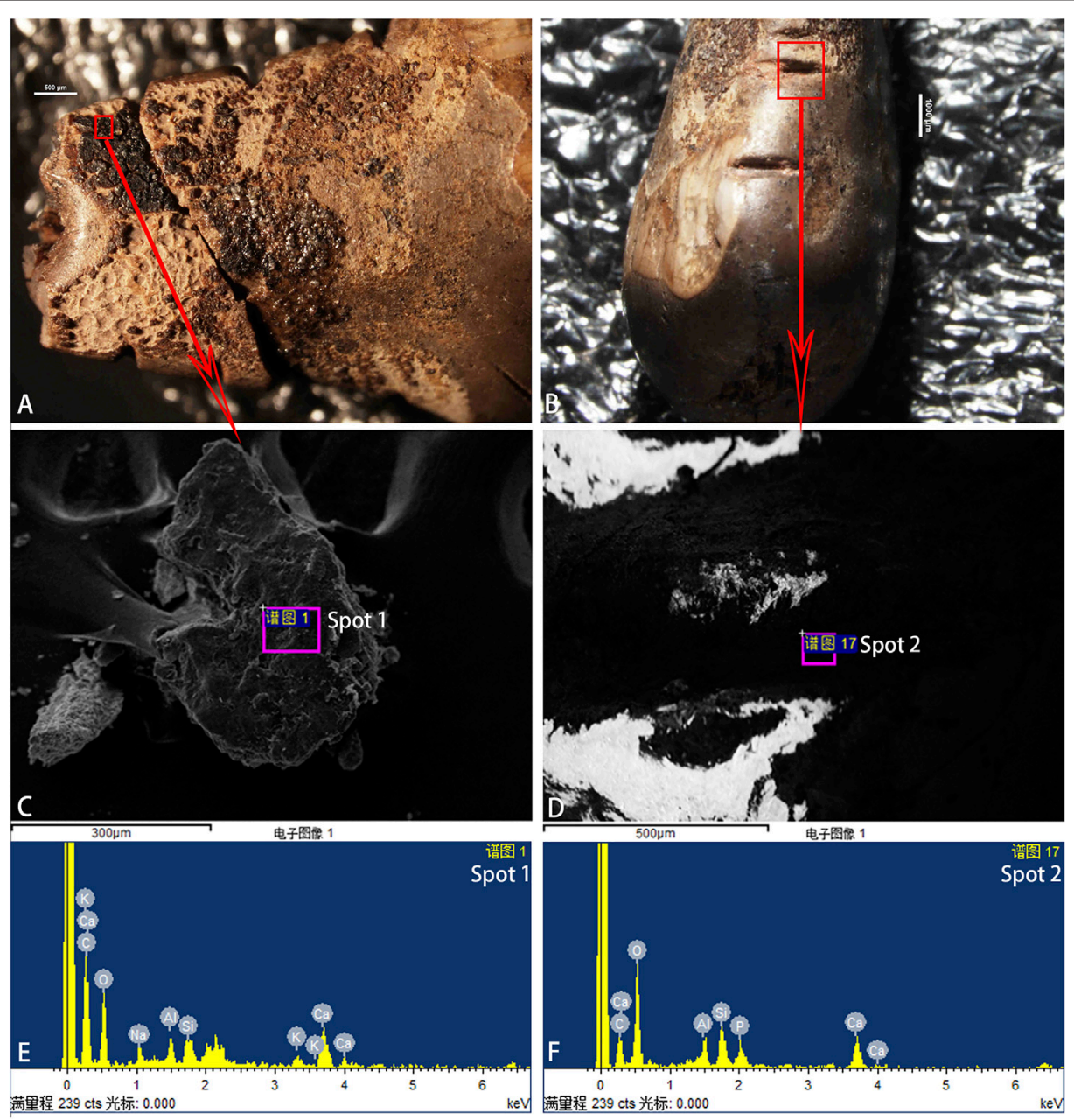

FIGURE 9 | (A,C) Area in which black residues were sampled under SEM; (B,D) Area in the background where comparative samples were analyzed under SEMEDS; (E,F) SEM-EDS spectra showing the chemical composition of the sampled residues; Scales: (A,D) $500 \mu \mathrm{m}$, (C) $300 \mu \mathrm{m}$, (B) $1000 \mu \mathrm{m}$.

TABLE 4 | Data for the elemental composition of the black residues and control sample analysed with SEM-EDS.

\begin{tabular}{lccccc} 
Elements & \multicolumn{2}{c}{ Black residues } & & \multicolumn{2}{c}{ Control sample } \\
\cline { 2 - 3 } & Weight \% & Atomic $\%$ & & Weight \% & Atomic \% \\
\hline $\mathrm{C}$ & 2.63 & 4.28 & & 22.47 & 31.17 \\
$\mathrm{O}$ & 60.27 & 73.61 & & 55.04 & 57.32 \\
$\mathrm{Na}$ & 4.73 & 4.02 & & - & - \\
$\mathrm{Al}$ & 5.16 & 3.74 & & 3.14 & 1.94 \\
$\mathrm{Si}$ & 4.97 & 3.46 & & 5.89 & 3.5 \\
$\mathrm{~K}$ & 4.04 & 2.02 & & - & - \\
$\mathrm{P}$ & - & - & & 3.95 & 2.12 \\
$\mathrm{Ca}$ & 18.2 & 8.87 & & 9.5 & 3.95 \\
Total & 100 & 100 & & 100 & 100 \\
\hline
\end{tabular}

sets of markings are relatively few. Most specimens come from Magdalenian (Vanhaeren and d'Errico, 2005) and Epipalaeolithic (d'Errico and Vanhaeren, 2002) burial contexts and from early Magdalenian sites from the Languedoc and Cantabrian coast
(Corchón, 1986; Sacchi, 1986). The making of such marking on a personal ornament probably acted as a way to signal its owners' identity (Vanhaeren and d'Errico, 2005), an information that would have been passed down from one individual to the next in the context of exchange. The idea that the QG10 perforated red deer canine represents an exotic item introduced in the site through social exchanges rather than by the hunting of a hind by QG10 visitors is reinforced by the fact that only a single item was found at the site. Furthermore, although present in the faunal assemblage, red deer remains are relatively few compared to other species, which likely reflects the biogeographic characteristics of the region during the Late Paleolithic (Norton et al., 2011; Pei et al., 2012; Gao et al., 2013; Feng Li et al., 2019).

In their recent synthesis, d'Errico et al. (2021) identified two geographically distinct traditions, east and west of the $112^{\circ} \mathrm{E}$ longitude, in ornamentation practices during the Late Paleolithic in North China. Geographically, QG10 is located within the region of the western tradition. However, typologically, QG10 is somewhat of a hybrid. On the one end, OESBs were found at the site, moreover in the same layer that yielded the item studied here. On the other hand, 
personal ornamentations made of perforated mammal teeth are in fact characteristic of the eastern tradition. Moreover, the eastern tradition seems to disappear from the Northern Chinese archaeological record c. $25 \mathrm{ka}$. This raises the question as to what is the place of QG10 in this symbolic geography. We argue that the discovery reported here and the ensuing interpretation is coherent with d'Errico et al.'s findings, and emphasize the importance to investigate Late Paleolithic population dynamics in Northeastern Eurasia in general, and Northern China in particular. The timespan between the "disappearance" of the eastern tradition and the occupation of QG10 appears too large to propose their phylogenetic link. Indeed, if QG10 should be associated to the "eastern tradition" one would expect that some Northern Chinese sites aged between 25 and $13 \mathrm{ka}$ and located east of the $112^{\circ} \mathrm{E}$ would have yielded perforated deer canine as well which is not the case at this time. On the other hand, in neighboring regions of China, red deer canines continue to be transformed and used as personal ornaments throughout the Upper and Late Paleolithic. Likewise, we cannot exclude the possibility that some members of the "western tradition" may have episodically decided to transform a deer canine into ornaments. However, given the know-how required to produce the QG10 specimen, which entails selecting and modifying the teeth, producing adhesives with a variety of mineral and organic ingredients, etc., it seems more likely that this complex knowledge was passed down through generations rather than being the results of a punctual experimentation. This idea is further supported by the decorations present on the bead, which were likely made by two, or perhaps three, individuals. Therefore, the most parsimonious interpretation for the presence of the single occurrence of a perforated red deer in the Ordos Plateau relates to social contacts and exchanges over long-distances. The origin of the tooth is perhaps to be found in Caucasus, Southern Siberia or Northeast Asia where similar items are found in the symbolic systems of hunter-gatherers living in these areas since the onset of the Upper Paleolithic (Derevianko and Rybin, 2003; Pitulko et al., 2012; Shunkov et al., 2020; Lbova, 2021; Tejero et al., 2021). Such contacts may have also favored the diffusion of microblade technology in Northern China (Keates, 2007; Kuzmin, 2007; Bae, 2010; Elston and Brantingham, 2002; Yi et al., 2016; Wang, 2018; Yue et al., 2021; Zhao et al., 2021) and participated in the intensification of the gene flow between Asian and Siberian populations during this critical period (Yang and $\mathrm{Fu}$, 2018; Sikora et al., 2019). Future research combining various cultural and biological proxies may help provide a better understanding of these population dynamics and their effect on the cultural systems of Late Glacial human groups in North China.

\section{CONCLUSION}

Zooarcheological and technological analyses of the QG10 tooth pendant reveal it was made from a right canine of a recently killed adult female red deer. Microscopic features on the perforation suggest the hole was made by rotation with the help of a hafted drill. The pendant was further modified in at least two, perhaps three, occasions by individuals whom left sets of notches and incisions on its surface. A right-handed individual made two series of notches, respectively, on the anterior and posterior aspects of the root in a single session. A left-handed individual made four incision in the middle of the occlusal surface crossing one another in a hashtag pattern. Finally, a right-handed individual bordered the hashtag pattern with five incisions, i.e., two on one side and three on the opposite one. Use wear on the perforation suggests the ornament was worn with the tooth crown facing upward. To ensure the stability of the beadwork, the tooth root appears to have been coated with an adhesive compound containing hematite and charcoal. Comparison with the Late Paleolithic ornamental traditions in Northern China suggests this particular specimen was obtained through social exchanges, perhaps from groups originating from the Caucasus, Southern Siberia or Northeastern Asia.

\section{DATA AVAILABILITY STATEMENT}

The original contributions presented in the study are included in the article/Supplementary Material, further inquiries can be directed to the corresponding author.

\section{AUTHOR CONTRIBUTIONS}

SZ, YZ, and FP designed the study. YZ, SZ, LD, FP, HW, JG, and $\mathrm{XG}$ conducted the study. YZ, LD and SZ wrote an initial version of the manuscript. All co-authors reviewed and made modifications to the final version of the manuscript.

\section{FUNDING}

This work was funded by grants from the National Natural Science Foundation of China (Nos. 41772025 and 41672023). LD acknowledge funding from the Sino-French PHC Xu Guangqi (grant number: 41230RB), the China-Shandong University Postdoctoral Exchange Programme, the Programme Talents (grant number: 191022_001), and the Grand Programme de Recherche "Human Past" of the Initiative d'Excellence (IdEx) of the Bordeaux University. PACEA (UMR5199 CNRS) is a Partner team of the Labex LaScArBx-ANR (program number: ANR-10-LABX-52).

\section{ACKNOWLEDGMENTS}

We thank Yemao Hou, Xun Jin and Junchi Liu for their technical help in analyses of the tooth pendant; we thank Francesco d'Errico for his insightful discussion and expertise on the analysis and interpretation of Paleolithic personal ornaments. We are also indebted to the colleagues and volunteers from IVPP and the Ningxia Institute of Cultural Relics and Archaeology for their participation in the field work at QG10. We also thank the editor and reviewers for their insightful comments which help improve the manuscript. 


\section{REFERENCES}

Albrethsen, S. E., and Petersen, E. B. (1976). Excavation of a Mesolithic Cemetery at Vedbæk, Denmark. Acta Archaeol. 47, 1-28.

Bae, K. (2010). Origin and Patterns of the Upper Paleolithic Industries in the Korean Peninsula and Movement of Modern Humans in East Asia. Quat. Int. 211, 103-112. doi:10.1016/j.quaint.2009.06.011

Balme, J., and O'Connor, S. (2019). Bead Making in Aboriginal Australia from the Deep Past to European Arrival: Materials, Methods, and Meanings. PaleoAnthropology 177, 195. doi:10.4207/PA.2019.ART130

Barge-Mahieu, , H., and Taborin, Y. (1991). Fiche canines résiduelles de cerf (appelées craches), Fiches typologiques de l'industrie osseuse préhistorique. Aix-en-Provence. Provence: Université de Provence.

Bar-Yosef Mayer, D. E., Groman-Yaroslavski, I., Bar-Yosef, O., Hershkovitz, I., Kampen-Hasday, A., Vandermeersch, B., et al. (2020). On Holes and Strings: Earliest Displays of Human Adornment in the Middle Palaeolithic. Plos One 15 (7), e0234924. doi:10.1371/journal.pone.0234924

Bar-Yosef Mayer, D. E. (2020). "Shell Beads of the Middle and Upper Palaeolithic: A Review of the Earliest Records," in Beauty and the Eye of the Beholder: Personal Adornments across the Millennia. Editors M. Mărgărit, and A. Boroneanț (Târgovişte: Cetatea de scaun), 11-25.

Bordreuil, M. (1966). Recherches sur les perles à ailettes. Congrès préhistorique de France, Compte-rendu de la XVIIIe Session, Ajaccio. Paris: Société préhistorique française.

Bosch, M., Buck, L., and Strauss, A. (2019). Location, Location, Location: Investigating Perforation Locations in Tritia Gibbosula Shells at Ksâr'Akil (Lebanon) Using Micro-CT Data. PaleoAnthropology 19, 52-63. doi:10.4207/ PA.2019.ART123

Bouzouggar, A., Barton, N., Vanhaeren, M., d'Errico, F., Collcutt, S., Higham, T., et al. (2007). 82,000-year-old Shell Beads from North Africa and Implications for the Origins of Modern Human Behavior. Proc. Natl. Acad. Sci. 104 (24), 9964-9969. doi:10.1073/pnas.0703877104

Brain, R. (1979). The Decorated Body. London: Hutchinson.

Bromage, T. G., and Boyde, A. (1984). Microscopic Criteria for the Determination of Directionality of Cutmarks on Bone. Am. J. Phys. Anthropol. 65 (4), 359-366. doi:10.1002/ajpa.1330650404

Camps-Faber, H. (1991). Objets de Parure. Aix-en-Provence: Université de Provence.

Carey, M. (1986). Beads and Beadwork of East and South Africa. Aylesbury: Bloomsbury Shire Publications.

Casella, E. C. (2012). "That's Just a Family Thing, You Know": Memory, Community Kinship, and Social Belonging in the Hagg Cottages of Cheshire, North-West England. Int. J. Histor Archaeol. 16 (2), 284-299. doi:10.1007/s10761-012-0179-9

Choyke, A. M. (2001). "Late Neolithic Red Deer Canine Beads and Their Imitations," in Crafting Bone: Skeletal Technologies through Time and Space. Editors A. Choyke, and L. Bartosiewicz (Oxford: BAR International Series), 937, 251-266.

Corchón, M. S. (1986). El Arte Mueble Paleolítico Cantábrico: Contexto Y Análisis Interno, 16. Madrid, Monografías: Centro de Investigación y Museo de Altamira, 482.

Cordwell, J. M., and Schwarz, R. A. (1979). The Fabrics of Culture: The Anthropology of Clothing and Adornment. Paris: Mouton.

Cristiani, E., and Borić, D. (2012). 8500-year-old Late Mesolithic Garment Embroidery from Vlasac (Serbia): Technological, Use-Wear and Residue Analyses. J. Archaeol. Sci. 39 (11), 3450-3469. doi:10.1016/j.jas.2012.05.016

Cristiani, E., Živaljević, I., and Borić, D. (2014). Residue Analysis and Ornament Suspension Techniques in Prehistory: Cyprinid Pharyngeal Teeth Beads from Late Mesolithic Burials at Vlasac (Serbia). J. Archaeol. Sci. 46, 292-310. doi:10. 1016/j.jas.2014.03.018

d'Errico, F., and Vanhaeren, M. (2015). "Upper Palaeolithic Mortuary Practices: Reflection of Ethnic Affiliation, Social Complexity, and Cultural Turnover," in Death Rituals, Social Order and the Archaeology of Immortality in the Ancient world:'Death Shall Have No Dominion. Editors C. Renfrew, M. J. Boyd, and I. Morley (Cambridge: Cambridge University Press), 45-62.

d'Errico, F., Pitarch Martí, A., Shipton, C., Le Vraux, E., Ndiema, E., Goldstein, S., et al. (2020). Trajectories of Cultural Innovation from the Middle to Later Stone Age in Eastern Africa: Personal Ornaments, Bone Artifacts, and Ocher from Panga Ya Saidi, Kenya. J. Hum. Evol. 141, 102737. doi:10.1016/j.jhevol.2019.102737

d'Errico, F., Pitarch Martí, A., Wei, Y., Gao, X., Vanhaeren, M., and Doyon, L. (2021). Zhoukoudian Upper Cave Personal Ornaments and Ochre: Rediscovery and Reevaluation. J. Hum. Evol. 161 (2021), 103088. doi:10.1016/j.jhevol.2021. 103088

d'Errico, F. (1991). Microscopic and Statistical Criteria for the Identification of Prehistoric Systems of Notation. Rock. Arts Res. 8 (2), 83-93.

d’Errico, F., Doyon, L., Zhang, S., Baumann, M., Lázničková-Galetová, M., Gao, X., et al. (2018b). The Origin and Evolution of Sewing Technologies in Eurasia and North America. J. Hum. Evol. 125, 71-86. doi:10.1016/j.jhevol.2018.10.004

d'Errico, F., and Vanhaeren, M. (2002). Criteria for Identifying Red Deer (Cervus elaphus) Age and Sex from Their Canines. Application to the Study of Upper Palaeolithic and Mesolithic Ornaments. J. Archaeol. Sci. 29 (2), 211-232. doi:10. 1006/jasc.2001.0687

d'Errico, F., Doyon, L., Colagé, I., Queffelec, A., Le Vraux, E., Giacobini, G., et al. (2018a). From Number Sense to Number Symbols. An Archaeological Perspective. Phil. Trans. R. Soc. B 373 (1740), 20160518. doi:10.1098/rstb.2016.0518

d'Errico, F. (1989). Palaeolithic Lunar Calendars: A Case of Wishful Thinking? Curr. Anthropol. 30 (1), 117-118. doi:10.1086/203721

d'Errico, F. (1992). Technology, Motion, and the Meaning of Epipaleolithic Art. Curr. Anthropol. 33 (1), 94-109. doi:10.1086/204039

d'Errico, F. (1993). La Vie Sociale De L'art Mobilier Paléolithique. Manipulation, Transport, Suspension Des Objets on Os, Bois De Cervidés, Ivoire. OJA 12 (2), 145-174. doi:10.1111/j.1468-0092.1993.tb00289.x

d'Errico, F. (1995). Image Analysis and 3-D Optical Surface Profiling of Upper Palaeolithic Mobiliary Art. Microsc. Anal. 51, 27-29.

d'Errico, F. (1998). "Palaeolithic Origins of Artificial Memory Systems: An Evolutionary Perspective," in Cognition and Material Culture: The Archaeology of Symbolic Storage. Editors C. Renfrew, and C. Scarre (Cambridge: McDonald Institute for Archaeological Research), 19-50.

d'Errico, F. (2009). A New Model and its Implications for the Origin of Writing: The La Marche Antler Revisited. Caj 5 (2), 163-206. doi:10.1017/ S095977430001502X

Densmore, F. (1918). Teton Sioux Music. Washington, D.C: Smithsonian Institution.

Derevianko, A. P., and Rybin, E. (2003). The Earliest Representaion of Symbolic Behavior by Paleolithic Humans in the Altai Mountains. Archaeol. Ethnol. Anthropol. Eurasia 3 (15), 27-50.

Domínguez-Rodrigo, M., de Juana, S., Galán, A. B., and Rodríguez, M. (2009). A New Protocol to Differentiate Trampling marks from Butchery Cut marks. J. Archaeol. Sci. 36 (12), 2643-2654. doi:10.1016/j.jas.2009.07.017

Dubin, L. S. (1999). North American Indian Jewelry and Adornment: From Prehistory to the Present. New York: Harry Abrams.

Elston, R. G., and Brantingham, P. J. (2002). Microlithic Technology in Northern Asia: A Risk-Minimizing Strategy of the Late Paleolithic and Early Holocene. Arch. P. Amer. Ant. Asso. 12 (1), 103-116. doi:10.1525/ap3a.2002.12.1.103

Fernández, E. Á., and Jöris, O. (2008). Personal Ornaments in the Early Upper Paleolithic of Western Eurasia: an Evaluation of the Record. Eurasian Prehistory 5 (2), 31-44

Fritz, C. (2009). Towards the Reconstruction of Magdalenian Artistic Techniques: the Contribution of Microscopic Analysis of Mobiliary Art. Caj 9 (2), 189-208. doi:10.1017/S0959774300015377

Gao, X., Wang, H. M., Pei, S. W., and Chen, F. Y. (2013). Shuidonggou-Excavation and Research Report (2003-2007). Beijing: Science Press.

Giacobini, G. (1999). “Les sépultures du Paléolithique supérieur d'Italie,” in Les faciès leptolithiques du nord-ouest méditerranéen: milieux naturels et culturels. Editor D. Sacchi (Carcassonne: SPF), 29-39.

Giering, K. L. (2018). Elk Ivory Pendants in Alberta. Archaeol. Surv. Alberta Occas. Paper 38, 92-101.

Goutas, N. (2004). Étude de la parure sur coquillages, dents animales et ivoire des niveaux gravettiens du gisement de la Gravette (Dordogne): charge identitaire et souplesse des normes techniques. Antiquités Nationales (Saint-Germain-enLaye) 36, 39-51.

Greer, K. R., and Yeager, H. W. (1967). Sex and Age Indications from Upper Canine Teeth of elk (wapiti). J. Wildl. Manage. 31 (3), 408-417. doi:10.2307/3798116

Grinnell, G. B. (2003). Blackfoot Lodge Tales: The story of a Prairie People. London: University of Nebraska Press.

Guan, Y., Tian, C., Peng, F., Guo, J., Wang, H., Zhou, Z., et al. (2020). Plant Diet during the Pleistocene-Holocene Transition in Northwest China: Evidence from Starch Remains from Pigeon Mountain Site in Ningxia Province. Quat. Int. 559, 110-118. doi:10.1016/j.quaint.2020.03.016 
Gwinnett, A. J., and Gorelick, L. (1991). Bead Manufacture at Hajar Ar-Rayhani, Yemen. The Biblical Archaeol. 54 (4), 187-196. doi:10.2307/3210280

Han, F. (2021). A Human Behavior Ecology Perspective on Microblade Technology of Pigeon Mountain Site. Beijing: University of the Chinese Academy of Sciences. Dissertation.

Hart, J. P., Shafie, T., Birch, J., Dermarkar, S., and Williamson, R. F. (2016). Nation Building and Social Signaling in Southern Ontario: A.D. 1350-1650. Plos One 11 (5), e0156178. doi:10.1371/journal.pone.0156178

Henshilwood, C. S., d'Errico, F., and Watts, I. (2009). Engraved Ochres from the Middle Stone Age Levels at Blombos Cave, South Africa. J. Hum. Evol. 57 (1), 27-47. doi:10.1016/j.jhevol.2009.01.005

Hillson, S. (2005). Teeth. Cambridge: Cambridge University Press.

Hodder, I. (1982). Symbols in Action: Ethnoarchaeological Studies of Material Culture. Cambridge: Cambridge University Press.

Huang, W. W., Zhang, Z. H., Fu, R. Y., Chen, B. F., Liu, J. Y., Zhu, M. Y., et al. (1986). Bone Artifacts and Ornaments from Xiaogushan Site of Haicheng, Liaoning Province. Acta Anthropol. Sin. 5 (3), 259-266.

Joyce, R. A. (2005). Archaeology of the Body. Annu. Rev. Anthropol. 34, 139-158. doi:10.1146/annurev.anthro.33.070203.143729

Kassam, A. (1988). Traditional Ornament: Some General Observations. Kenya. Past. Pres. 20 (1), 11-16.

Keates, S. G. (2007). "Microblade Technology in Siberia and Neighbouring Regions: an Overview," in Origin and Spread of Microblade Technology in Northern Asia and North America. Editors Y. V. Kuzmin, S. G. Keates, and C. Shen, and (Burnaby, British Columbia: Archaeology Press), 125-146.

Kidd, K. E. (1986). Blackfoot Ethnography. Manuscript Series 8. Edmonton, Alberta: Archaeological Survey of Alberta.

Kidder, A. V. (1957). Perforated elk Teeth: a Functional and Historical Analysis. Am. Antiq. 22 (4), 381-387. doi:10.2307/276137

Kuhn, S. L., and Stiner, M. C. (2007). Paleolithic Ornaments: Implications for Cognition, Demography and Identity. Diogenes 54 (2), 40-48. doi:10.1177/ 0392192107076870

Kuper, H. (1973). Costume and Identity. Comp. Stud. Soc. Hist. 15 (3), 348-367. doi:10.1017/s0010417500007143

Kuzmin, Y. V. (2007). "Geoarchaeological Aspects of the Origin and Spread of Microblade Technology in Northern and Central Asia," in Origin and Spread of Microblade Technology in Northern Asia and North America. Editors Y. V. Kuzmin, S. G. Keates, and C. Shen (Burnaby, British Columbia: Archaeology Press).

Ladier, E., and Welté, A. C. (1994). Les Bijoux de la Préhistoire. La parure Magdalénienne dans la vallée de l'Aveyron. Montauban: Museum d'Histoire Naturelle.

Langley, M. C., Clarkson, C., and Ulm, S. (2019). Symbolic Expression in Pleistocene Sahul, Sunda, and Wallacea. Quat. Sci. Rev. 221, 105883. doi:10. 1016/j.quascirev.2019.105883

Langley, M. C., Amano, N., Wedage, O., Deraniyagala, S., Pathmalal, M. M., Perera, N., et al. (2020). Bows and Arrows and Complex Symbolic Displays 48,000 Years Ago in the South Asian Tropics. Sci. Adv. 6 (24), eaba3831. doi:10.1126/sciadv.aba3831

Lbova, L. (2021). Personal Ornaments as Markers of Social Behavior, Technological Development and Cultural Phenomena in the Siberian Early Upper Paleolithic. Quat. Int. 573, 4-13. doi:10.1016/j.quaint.2020.05.035

Li, F., Kuhn, S. L., Bar-Yosef, O., Chen, F.-y., Peng, F., and Gao, X. (2019). History, Chronology and Techno-Typology of the Upper Paleolithic Sequence in the Shuidonggou Area, Northern China. J. World Prehist. 32 (2), 111-141. doi:10. 1007/s10963-019-09129-w

Li, Z., Doyon, L., Li, H., Wang, Q., Zhang, Z., Zhao, Q., et al. (2019). Engraved Bones from the Archaic Hominin Site of Lingjing, Henan Province. Antiquity 93 (370), 886-900. doi:10.15184/aqy.2019.81

Loendorf, L. L. (2010). "Crow Indian elk Love-Medicine and Rock Art in Montana and Wyoming," in Seeing and Knowing. Editors G. Blundell, C. Chippindale, and B. Smith (Johannesburg: Wits University Press), 153-162.

Majkić, A., Evans, S., Stepanchuk, V., Tsvelykh, A., and d'Errico, F. (2017). A Decorated Raven Bone from the Zaskalnaya VI (Kolosovskaya) Neanderthal Site, Crimea. Plos One 12 (3), e0173435. doi:10.1371/journal.pone.0173435

Majkić, A., d’Errico, F., Milošević, S., Mihailović, D., and Dimitrijević, V. (2018). Sequential Incisions on a Cave Bear Bone from the Middle Paleolithic of Pešturina Cave, Serbia. J. Archaeol Method Theor. 25 (1), 69-116. doi:10.1007/ s10816-017-9331-5
Malinowski, B. (1922). Argonauts of the Western Pacific: An Account of Native Enterprise and Adventure in the Archipelagoes of Melanesian New Guinea. London: Routledge.

Marshack, A., and d'Errico, F. (1989). On Wishful Thinking and Lunar "Calendars". Curr. Anthropol. 30 (4), 491-500. doi:10.1086/203773

McAdam, L., and Davidson, I. (2018). "Beads and Boundaries," in The Archaeology of Portable Art. Editors M. C. Langley, M. Lister, D. Wright, and S. K. May (London: Routledge), 220-240. doi:10.4324/9781315299112-14

McAdam, L. E. (2008). Beads across Australia: An Ethnographic and Archaeological View of the Patterning of Aboriginal Ornaments. Armidale: University of New England, Ph.D Dissertation.

McCabe, R. E. (1982). "Elk and Indians: Historical Values and Perspectives," in Elk of North America: Ecology and Management. Editors J. W. Thomas, and D. E. Toweill (Pennsylvania: Stackpole Books), 61-123.

Morris, J., and Preston-Whyte, E. (1994). Speaking with Beads: Zulu Arts from Southern Africa. London: Thames and Hudson.

Newell, R. R., Kielman, D., Constandse-Westermann, T. S., Van der Sanden, W. A. B., and Van Gijn, A. (1990). An Inquiry into the Ethnic Resolution of Mesolithic Regional Groups: The Study of Their Decorative Ornaments in Time and Space. Leiden: Brill.

Norton, C. J., Jin, C., Wang, Y., and Zhang, Y. (2011). "Rethinking the Palearctic-oriental Biogeographic Boundary in Quaternary China," in Asian Paleoanthropology: From Africa to China and beyond. Editors C. J. Norton, and D. R. Braun (Dordrecht: Springer Netherlands), 81-100. doi:10.1007/978-90-481-9094-2_7

O'Shea, J., and Zvelebil, M. (1984). Oleneostrovski Mogilnik: Reconstructing the Social and Economic Organization of Prehistoric Foragers in Northern Russia. J. Anthropol. Archaeol. 3 (1), 1-40. doi:10.1016/0278-4165(84)90011-4

Pearson, M. P. (1999). The Archaeology of Death and Burial. Sutton: Phoenix Mill.

Pei, S., Gao, X., Wang, H., Kuman, K., Bae, C. J., Chen, F., et al. (2012). The Shuidonggou Site Complex: New Excavations and Implications for the Earliest Late Paleolithic in North China. J. Archaeol. Sci. 39 (12), 3610-3626. doi:10.1016/j.jas.2012.06.028

Pei, W. C. (1939). The Upper Cave Industry of Choukoutien. Palaeontol. Sinica (Series D) 9, 1-58.

Peng, F., Guo, J., Wang, H., and Gao, X. (2017). Another Significant Discovery from Pigeon Mountain in Ningxia. Beijing: Chinese Cultural Relics News. (In Chinese).

Pitarch Martí, A., Wei, Y., Gao, X., Chen, F., and d'Errico, F. (2017). The Earliest Evidence of Coloured Ornaments in China: The Ochred Ostrich Eggshell Beads from Shuidonggou Locality 2. J. Anthropol. Archaeol. 48, 102-113. doi:10.1016/j.jaa.2017.07.002

Pitulko, V. V., Pavlova, E. Y., Nikolskiy, P. A., and Ivanova, V. V. (2012). The Oldest Art of the Eurasian Arctic: Personal Ornaments and Symbolic Objects from Yana RHS, Arctic Siberia. Antiquity 86 (333), 642-659. doi:10.1017/S0003598X00047827

Rainio, R., and Mannermaa, K. (2014). Tracing the Rattle of Animal Tooth Pendants from the Middle Neolithic Graves of Ajvide, Gotland, Sweden. World Archaeol. 46 (3), 332-348. doi:10.1080/00438243.2014.909105

Rainio, R., Gerasimov, D. V., Girya, E. Y., and Mannermaa, K. (2021). Prehistoric Pendants as Instigators of Sound and Body Movements: A Traceological Case Study from Northeast Europe, C. 8200 Cal. BP. Caj 31, 639-660. doi:10.1017/ S0959774321000275

Rigaud, S., Vanhaeren, M., Queffelec, A., Le Bourdon, G., and d'Errico, F. (2014). The Way We Wear Makes the Difference: Residue Analysis Applied to Mesolithic Personal Ornaments from Hohlenstein-Stadel (Germany). Archaeol Anthropol. Sci. 6 (2), 133-144. doi:10.1007/s12520-013-0169-9

Rigaud, S., d'Errico, F., and Vanhaeren, M. (2015). Ornaments Reveal Resistance of North European Cultures to the Spread of Farming. Plos One 10 (4), e0121166. doi:10.1371/journal.pone.0121166

Rigaud, S., Manen, C., and García-Martínez de Lagrán, I. (2018). Symbols in Motion: Flexible Cultural Boundaries and the Fast Spread of the Neolithic in the Western Mediterranean. Plos One 13 (5), e0196488. doi:10.1371/journal.pone.0196488

Rigaud, S. (2011). La parure: traceur de la géographie culturelle et des dynamiques de peuplement au passage Mésolithique-Néolithique en Europe. Bordeaux: Université Bordeaux 1. Ph.D Dissertation.

Rodríguez-Vidal, J., d’Errico, F., Pacheco, F. G., Blasco, R., Rosell, J., Jennings, R. P., et al. (2014). A Rock Engraving Made by Neanderthals in Gibraltar. Proc. Natl. Acad. Sci. USA 111 (37), 13301-13306. doi:10.1073/pnas.1411529111

Sacchi, D. (1986). Le Paléolithique supérieur du Languedoc Occidental et du Roussillon. Paris: Persée-Portail des revues scientifiques en SHS, CNRS.

Sanders, J. M. (2002). Ethnic Boundaries and Identity in Plural Societies. Annu. Rev. Sociol. 28 (1), 327-357. doi:10.1146/annurev.soc.28.110601.140741 
Sehasseh, E. M., Fernandez, P., Kuhn, S., Stiner, M., Mentzer, S., Colarossi, D., et al. (2021). Early Middle Stone Age Personal Ornaments from Bizmoune Cave, Essaouira, Morocco. Sci. Adv. 7 (39), eabi8620. doi:10.1126/sciadv.abi8620

Shidrang, S. (2018). "The Middle to Upper Paleolithic Transition in the Zagros: the Appearance and Evolution of the Baradostian," in The Middle and Upper Paleolithic Archeology of the Levant and beyond. Editors Y. Nishiaki, and T. Akazawa (Singapore: Springer), 133-156. doi:10.1007/978-981-10-6826-3_10

Shipman, P., and Rose, J. (1983). Early Hominid Hunting, Butchering, and Carcass-Processing Behaviors: Approaches to the Fossil Record. J. Anthropol. Archaeol. 2 (1), 57-98. doi:10.1016/0278-4165(83)90008-9

Shunkov, M. V., Fedorchenko, A. Y., Kozlikin, M. B., and Derevianko, A. P. (2020). Initial Upper Palaeolithic Ornaments and Formal Bone Tools from the East Chamber of Denisova Cave in the Russian Altai. Quat. Int. 559, 47-67. doi:10. 1016/j.quaint.2020.07.027

Sikora, M., Pitulko, V. V., Sousa, V. C., Allentoft, M. E., Vinner, L., Rasmussen, S., et al. (2019). The Population History of Northeastern Siberia since the Pleistocene. Nature 570 (7760), 182-188. doi:10.1038/s41586-019-1279-z

Steele, T. E., Álvarez-Fernández, E., and Hallet-Desguez, E. (2019). A Review of Shells as Personal Ornamentation during the African Middle Stone Age. PaleoAnthropology 24, 24-51. doi:10.4207/PA.2019.ART122

Stiner, M. C., Kuhn, S. L., and Güleç, E. (2013). Early Upper Paleolithic Shell Beads at Üçağılı Cave I (Turkey): Technology and the Socioeconomic Context of Ornament Life-Histories. J. Hum. Evol. 64 (5), 380-398. doi:10.1016/j.jhevol.2013.01.008

Sturtevant, W. C. (1978). Handbook of North American Indians. Washington: Smithsonian Institution.

Taborin, Y. (2004). Langage Sans Parole. La Parure Aux Temps Préhistoriques. Paris: La Maison des Roches éditeur.

Tejero, J.-M., Rabinovich, R., Yeshurun, R., Abulafia, T., Bar-Yosef, O., Barzilai, O., et al. (2021). Personal Ornaments from Hayonim and Manot Caves (Israel) Hint at Symbolic Ties between the Levantine and the European Aurignacian. J. Hum. Evol. 160, 102870. doi:10.1016/j.jhevol.2020.102870

Tejero, J.-M., Bar-Oz, G., Bar-Yosef, O., Meshveliani, T., Jakeli, N., Matskevich, Z., et al. (2021). New Insights into the Upper Palaeolithic of the Caucasus through the Study of Personal Ornaments. Teeth and Bones Pendants from Satsurblia and Dzudzuana Caves (Imereti, Georgia). Plos One 16 (11), e0258974. doi:10. 1371/journal.pone.0258974

Vanhaeren, M., and d'Errico, F. (2003). Le mobilier funéraire de la Dame de SaintGermain-la-Rivière (Gironde) et l'origine paléolithique des inégalités. paleo 15, 195-238. doi:10.4000/paleo.1293

Vanhaeren, M., and d'Errico, F. (2005). Grave Goods from the Saint-Germain-LaRivière Burial: Evidence for Social Inequality in the Upper Palaeolithic. J. Anthropol. Archaeol. 24 (2), 117-134. doi:10.1016/j.jaa.2005.01.001

Vanhaeren, M., and d'Errico, F. (2002). "The Body Ornaments Associated with the Burial," in Portrait of the Artist as a Child. The Gravettian Human Skeleton Fro the Abrigo Do Lagar Velho and its Archaeological Context. Editors J. Zilhão, and E. Trinkaus (Lisboa: Instituto Português de Arqueologia), 154-186.

Vanhaeren, M., and d'Errico, F. (2006). Aurignacian Ethno-Linguistic Geography of Europe Revealed by Personal Ornaments. J. Archaeol. Sci. 33 (8), 1105-1128. doi:10.1016/j.jas.2005.11.017

Vanhaeren, M., and D’Errico, F. (2017). Les incisives de bouquetin perforées de Praileaitz I (Deba, Gipuzkoa). Analyse archéozoologique et technologique. Munibe Monogr. Anthropol. Archaeol. Ser. 1 (1), 485-492. doi:10.21630/mmaas.2017.1.18

Vanhaeren, M., Wadley, L., and d'Errico, F. (2019). Variability in Middle Stone Age Symbolic Traditions: The marine Shell Beads from Sibudu Cave, South Africa. J. Archaeol. Sci. Rep. 27, 101893. doi:10.1016/j.jasrep.2019.101893

Wang, Y. (2018). Emergence and Dispersal of the Micro-blade Technology in North China. Acta Anthropol. Sin. 37 (4), 565-576. doi:10.16359/j.cnki.cn11-1963/q.2018. 0045(in Chinese with English abstract)

Wei, Y., d'Errico, F., Vanhaeren, M., Li, F., and Gao, X. (2016). An Early Instance of Upper Palaeolithic Personal Ornamentation from China: The Freshwater Shell Bead from Shuidonggou 2. Plos One 11 (5), e0155847. doi:10.1371/journal.pone.0155847

Wei, Y., d'Errico, F., Vanhaeren, M., Peng, F., Chen, F., and Gao, X. (2017). A Technological and Morphological Study of Late Paleolithic Ostrich Eggshell Beads from Shuidonggou, North China. J. Archaeol. Sci. 85, 83-104. doi:10. 1016/j.jas.2017.07.003

Werner, J. J., and Miller, J. M. (2018). Distinguishing Stone Age Drilling Techniques on Ostrich Eggshell Beads: an Experimental Approach. J. Archaeol. Sci. Rep. 22, 108-114. doi:10.1016/j.jasrep.2018.09.020
White, T. D., and Folkens, P. A. (2005). The Human Bone Manual. Burlington: Elsevier.

White, R. (1989). "Production Complexity and Standardisation in Early Aurignacian Bead and Pendant Manufacture: Evolutionary Implications," in The Human Revolution: Behavioural and Biological Perspectives on the Origins of Modern Humans. Editors P. Mellars, and C. Stringer (Princeton: Princeton University Press), 366-390.

White, R. (2007). "Systems of Personal Ornamentation in the Early Upper Palaeolithic: Methodological Challenges and New Observations," in Rethinking the Human Revolution: New Behavioural and Biological Perspectives on the Origin and Dispersal of Modern Humans. Editors P. Mellars, K. Boyle, C. Stringer, and O. Bar-Yosef (Cambridge: McDonald Institue for Archeological Research), 287-302.

Wissler, C., and Duvall, D. (1908). Mythology of the Blackfoot Indians. Anthropological Papers of the American Museum of Natural History, Vol. II. New York: American Museum of Natural History. Part 1.

Yang, M. A., and Fu, Q. (2018). Insights into Modern Human Prehistory Using Ancient Genomes. Trends Genet. 34 (3), 184-196. doi:10.1016/j.tig.2017.11.008

Yang, Y., Wang, C., Gao, X., Gu, Z., Wang, N., Xiao, T., et al. (2018). Micro-CT Investigation of Ostrich Eggshell Beads Collected from Locality 12, the Shuidonggou Site, China. Archaeol Anthropol. Sci. 10 (2), 305-313. doi:10. 1007/s12520-016-0355-7

Yi, M., Barton, L., Morgan, C., Liu, D., Chen, F., Zhang, Y., et al. (2013). Microblade Technology and the Rise of Serial Specialists in north-central China. J. Anthropol. Archaeol. 32 (2), 212-223. doi:10.1016/j.jaa.2013.02.001

Yi, M., Gao, X., Li, F., and Chen, F. (2016). Rethinking the Origin of Microblade Technology: a Chronological and Ecological Perspective. Quat. Int. 400, 130-139. doi:10.1016/j.quaint.2015.07.009

Yi, M., Gao, X., Chen, F., Pei, S., and Wang, H. (2021). Combining Sedentism and Mobility in the Palaeolithic-Neolithic Transition of Northern China: the Site of Shuidonggou Locality 12. Antiquity 95 (380), 292-309. doi:10.15184/aqy.2021.9

Yue, J.-P., Yang, S.-X., Li, Y.-Q., Storozum, M., Hou, Y.-M., Chang, Y., et al. (2021). Human Adaptations during MIS 2: Evidence from Microblade Industries of Northeast China. Palaeogeogr. Palaeoclimatol. Palaeoecol. 567 (2), 110286. doi:10.1016/j.palaeo.2021.110286

Zhang, S., Doyon, L., Zhang, Y., Gao, X., Chen, F., Guan, Y., et al. (2018). Innovation in Bone Technology and Artefact Types in the Late Upper Palaeolithic of China: Insights from Shuidonggou Locality 12. J. Archaeol. Sci. 93 (3), 82-93. doi:10.1016/j.jas.2018.03.003

Zhang, S. Q., Peng, F., Zhang, Y., Guo, j. L., Wang, H. M., Huang, C., et al. (2019). Taphonomic Observation of Faunal Remains from the Gezishan Locality 10 in Ningxia Hui Autonomous Region. Acta Anthropol. Sin. 38 (2), 232-244. doi:10. 16359/j.cnki.cn11-1963/q.2019.0019 (in Chinese with English abstract)

Zhao, C., Wang, Y., Gu, W., Wang, S., Wu, X., Gao, X., et al. (2021). The Emergence of Early Microblade Technology in the Hinterland of North China: a Case Study Based on the Xishi and Dongshi Site in Henan Province. Archaeol Anthropol. Sci. 13 (6), 1-16. doi:10.1007/s12520-021-01338-9

Conflict of Interest: The authors declare that the research was conducted in the absence of any commercial or financial relationships that could be construed as a potential conflict of interest.

The handling editor is currently co-organizing a Research Topic with one of the authors SZ, and confirms the absence of any other collaboration.

Publisher's Note: All claims expressed in this article are solely those of the authors and do not necessarily represent those of their affiliated organizations, or those of the publisher, the editors and the reviewers. Any product that may be evaluated in this article, or claim that may be made by its manufacturer, is not guaranteed or endorsed by the publisher.

Copyright (๑ 2022 Zhang, Doyon, Peng, Wang, Guo, Gao and Zhang. This is an open-access article distributed under the terms of the Creative Commons Attribution License (CC BY). The use, distribution or reproduction in other forums is permitted, provided the original author(s) and the copyright owner(s) are credited and that the original publication in this journal is cited, in accordance with accepted academic practice. No use, distribution or reproduction is permitted which does not comply with these terms. 